\title{
Chapter 3 \\ Linkage Between Agriculture, Poverty and Malnutrition in India
}

\author{
Ashok Gulati and Ranjana Roy
}

\subsection{Introduction}

Despite the high economic growth rate over the last 10-15 years, a large section of the population remains undernourished. This has raised questions regarding the quality of India's growth story, especially in terms of its inclusiveness, and its impact on the poor and the malnourished. It has attracted attention in world literature as well as among Indian policymakers. It requires a deeper analysis of agricultural performance and its effects on poverty (especially rural) and malnutrition over a reasonably long period of time. It is precisely this issue that has been attempted in this chapter.

India has come a long way since independence in terms of reduction in poverty and malnutrition. The poverty headcount ratio was as high as 45\% in 1993-94; this declined to $22 \%$ in 2011-12 following the Tendulkar Methodology for measurement of poverty (Planning Commission 2014). According to UNICEF, nearly half of all deaths among children under five in Asia and Africa are attributable to undernutrition. Recent National Family Health Survey Data (NFHS 4, 2015-16) on India indicates that $38.4 \%$ of Indian children (under the age of five years)were stunted ${ }^{1}$

\footnotetext{
${ }^{1}$ Low height for age/Stunted: is defined as the percentage of children, aged 0-59 months, whose height for age is below 2 standard deviations from the median of the reference population.

Low weight for height/Wasting: measures body mass in relation to body length. Children whose $Z$-score is below minus 2 standard deviations from the median of reference population are considered wasted for their height.

Weight for age/Underweight: is a composite index of height for age and weight for height. Children whose weight for age is below minus two standard deviations from median of the reference population are classified as underweight.
}

\footnotetext{
A. Gulati $(\bowtie) \cdot$ R. Roy

Indian Council for Research on International Economic Relations, New Delhi, India e-mail: agulati115@gmail.com

R. Roy

e-mail: thisisranjana@gmail.com

(C) The Author(s) 2021

A. Gulati et al. (eds.), Revitalizing Indian Agriculture and Boosting

Farmer Incomes, India Studies in Business and Economics,

https://doi.org/10.1007/978-981-15-9335-2_3
} 


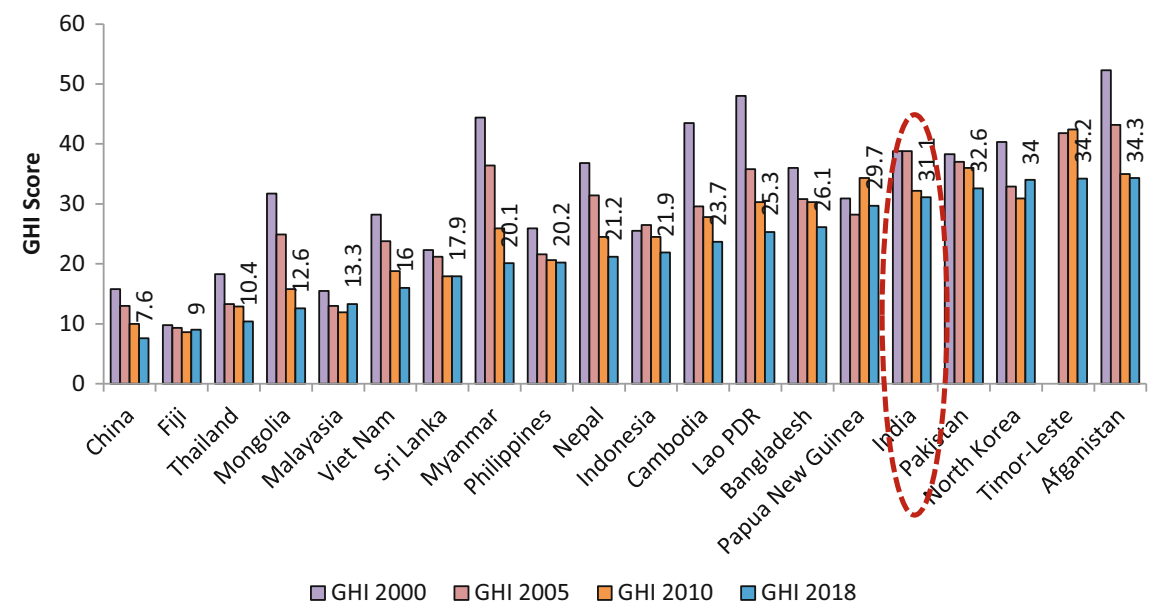

Fig. 3.1 GHI scores: South, East and Southeast Asia. Source https://www.globalhungerindex.org/

while $21 \%$ were wasted and $35.7 \%$ were underweight. The situation seems a little better in comparison to the NFHS-3 (2005-06) results, in which the corresponding figures were $48.0 \%$ (stunted), $19.8 \%$ (wasted) and $42.5 \%$ (underweight). The share of thin women (men) $\left(\mathrm{BMI}<18.5 \mathrm{~kg} / \mathrm{m}^{2}\right)$ in the country declined from $35.5(34.2) \%$ in 2005-06 to $22.9(20.2) \%$ in 2015-16. The prevalence of anaemia among adults was almost unchanged in the last decade. In absolute terms, the current level of malnourishment is still high and remains an enigma.

Globally, India performs very lowly on hunger parameters. According to the International Food Policy Research Institute's (IFPRI) Global Hunger Index (GHI), ${ }^{2}$ India has a score of 31.1 and has a global rank of 103 out of 119 countries (GHI, 2018). India's performance on this index is much worse than some of its neighbours-Sri Lanka, Nepal and Bangladesh (Fig. 3.1).

Even though Indian hunger statistics have gotten better over the years (the fall in GHI score since the year 2000 in Fig. 3.1), the relatively high level of deprivation (measured through the GHI 2018 score) has ensured that India ranks poorly in the global hunger index.

A country-level average masks individual levels of deprivation. Within India, statistics reveal that rural households are more at risk of malnutrition than urban households. There is also a large inter-state variation in the pattern and trends. In some states, namely Uttar Pradesh, Odisha, Bihar and MP, the infant mortality rate (IMR) remained as high as 50 per 1000 live births, while in Goa and Kerala, IMR was around 10 per 1000 live births.

\footnotetext{
${ }^{2} \mathrm{GHI}$ is a global comprehensive index that measures, tracks and compares levels of hunger between countries and regions overtime. A zero GHI score implies zero hunger.
} 
Severe malnourishment among the rural population and the high level of dependence on agriculture for livelihood indicate that there is a strong link between agriculture and nutrition in developing countries. This association for India is presented graphically using scatter diagrams in the annexure (Figs. 3.20, 3.21, 3.22, 3.23). The link between agriculture and nutrition is not direct - there are several ways in which agriculture affects nutritional status. The World Bank outlines five pathways through which agriculture can affect the nutritional status of the population: (i) increased food production leading to increased food consumption; (ii) sale of agricultural commodities leading to increased incomes; (iii) empowerment of women playing a significant role in improving household food security and nutritional outcomes; (iv) decline in food shortage reducing real prices of food; and (v) agricultural growth leading to increased national income which in turn induces a reduction in poverty (Report No: 40196-GLB, World Bank 2007). There have been many studies that have examined this linkage in India. A study by Gulati et al. (2012) based on NFHS-3 (2005-06) data shows that agriculture can have a positive effect on nutritional outcomes. Intervention is also required to improve education, health, sanitation infrastructure, care and feeding practices. A study by Vepa et al. (2014) shows that increase in female agricultural wages has a positive impact on child nutritional status. But a household level study by Bhagowaliya (2012), based on the India Human Development Survey (IHDS 2005), finds that income is a better determinant of nutrition in urban areas than in rural areas and they find a weak relationship between agriculture growth and nutritional outcomes.

In this study, we investigate the possible interaction between agriculture and malnutrition to identify factors that have a significant impact on malnutrition and to assess whether success stories can be replicated in underperforming states as well using more recent data.

The chapter is organised as follows:

After this brief Introduction, we spell out the methodological framework for looking at the linkages between agriculture, poverty and malnutrition in Sect. 3.2. Section 3.3 highlights the performance of Indian Agricultural Sector. In sect. 3.4 we look at the current status with respect to poverty and malnutrition in India and how it has changed over time. In sect. 3.5 we test the hypothesis that agricultural performance does affect poverty and malnutrition status. In sect. 3.6 we go beyond agriculture and look at the influence of other socio-economic factors on malnutrition. Finally, in Sect. 3.7 we present some concluding remarks based on our empirical and econometric analysis.

\subsection{Methodology}

In this chapter, we briefly explore the causes of child malnutrition and emphasise variables such as agricultural performance, women's education, child care and feeding practices, access to health infrastructure and household amenities in influencing nutritional outcomes. These key determinants are selected based on previous studies 
as well as UNICEF's conceptual framework on causes of malnutrition (UNICEF 2013; Gulati et al 2012; Bhagowaliya 2012; Kadiyala 2014).

Three indicators of child under-nutrition and two indicators of adult malnutrition are used in the analysis. These are (i) infant mortality rate per 1000 live births (ii) percentage of stunted children and (iii) percentage of underweight children (iv) percentage of thin women $\left(B M I<18.5 \mathrm{~kg} / \mathrm{m}^{2}\right)$ and $(\mathrm{v})$ percentage of thin men $(\mathrm{BMI}<$ $18.5 \mathrm{~kg} / \mathrm{m}^{2}$ ). The data on child under-nutrition is obtained from two National Family Health Survey Data sets relating to the periods 2005-06 and 2015-16 (NFHS-3 2005-06 and NFHS-4 2015-16). Data on adult malnutrition has also been taken from two NFHS data sets pertaining to $2005-06$ and $2015-16 .{ }^{3}$ These datasets also provide information on literacy, household sanitation, access to health facilities and child care and feeding practices.

Data on the agricultural performance of states have been taken from the Central Statistical Organisation (for gross value of output from agriculture and allied activities) and Directorate of Economics and Statistics (for gross cropped area). The triennial average of the gross value of output at constant (2011-12) prices per hectare of gross cropped area, which is basically gross land productivity, is used to measure agricultural performance across states.

Generally, panel data analysis with long time series and cross-section data at the household level is better suited to test the impact of different relevant variables on malnutrition. But the dearth of data has forced us to contain our analysis within a cross-section of states over two-time points, viz., 2005-06 and 2015-16. Panel data fixed effects and random-effects models are used to analyse the link between malnutrition and various factors affecting malnutrition. We also investigated the relationship between poverty, agricultural performance and other socio-economic variables. The Hausman test has been run to confirm the appropriate model (fixed effects or random-effects) to apply.

\subsection{Performance of Indian Agricultural Sector}

India has come a long way since independence-from being a food scarce economy to a self-sufficient one with some net export surpluses. But Indian agriculture is still characterised by high volatility. If we have a look at the plan wise agricultural growth rates, agricultural GDP has grown at $2.7 \%$ per annum during the 12 th plan period (2012-13 to 2016-17), which is lower than the growth in the previous plan period (4.1\% in 2007-08 to 2011-12) (Fig. 3.2). Consecutive droughts in 201415 and 2015-16 led to the decline in agricultural GDP growth during the12th plan period. The sector is still strongly affected by the vagaries of nature. The coefficient

\footnotetext{
${ }^{3}$ In the previous NFHS rounds, data on child malnutrition has been collected for children below age three while for the recent rounds, information has been collected for children below age five. Due to comparability issues, we chose not to consider NFHS-1 and NFHS-2. Similarly, in the previous NFHS rounds, information was gathered only for the ever-married women. For comparability, we have based our analysis of adult malnutrition on the latest two datasets of NFHS.
} 


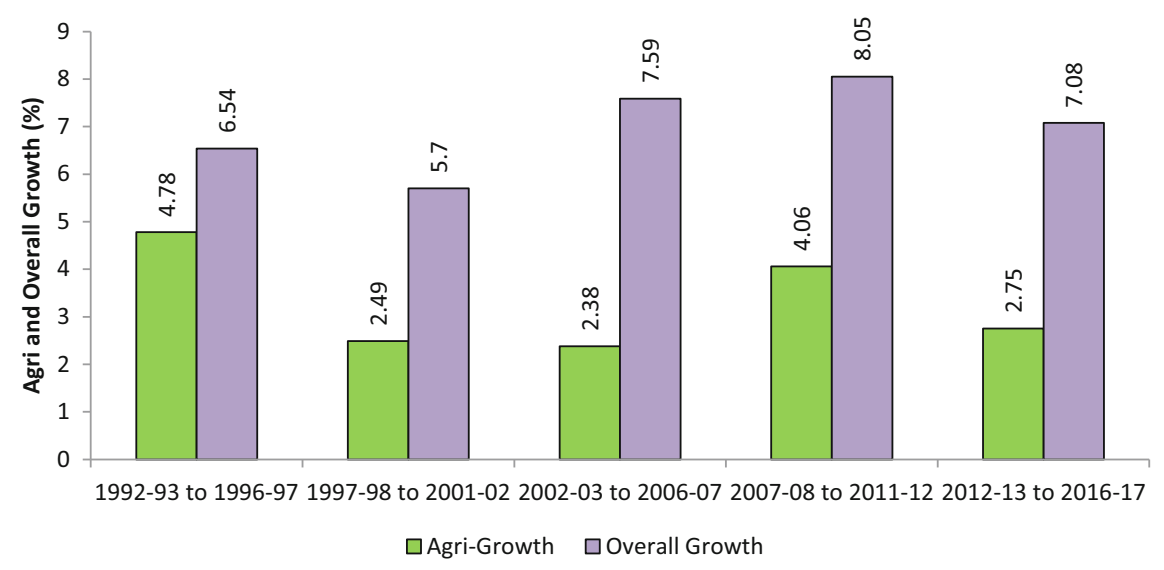

Fig. 3.2 Agriculture and overall GDP growth in India during five-year plans (1992-93 to 2016-17). Source Central Statistical Office

of variation of agriculture growth for the period of 1991-92 to 2016-17 and 2000-01 to $2016-17$ are $126.3 \%$ and $125.8 \%$ respectively, which is very high compared to the coefficient of variation of overall GDP growth (24\% and $25 \%$ respectively) in the same period.

To assess the performance of agriculture over time, one can look at different variables, such as gross value of output from agriculture (GVOA) per ha of net sown area (NSA) or gross state domestic product from agriculture (GSDPA) per agricultural household. The state-wise GVOA per hectare of NSA (GVOA/ha) basically measures net land productivity (Fig. 3.3). States specialising in fruits, vegetables and livestock products (fruits in Himachal Pradesh; fruits, flowers and plantation

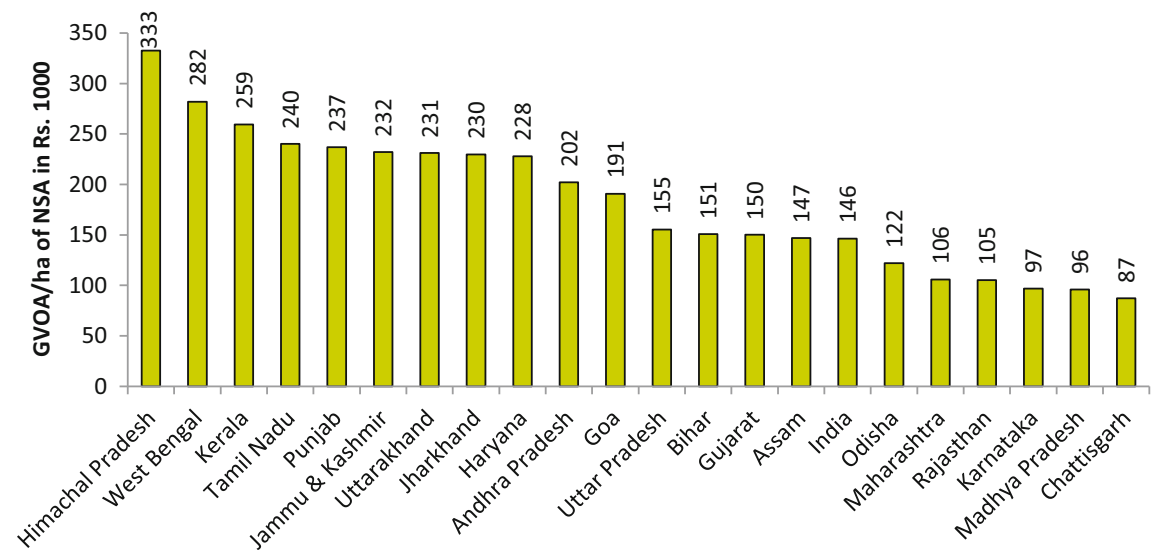

Fig. 3.3 State-wise gross value of output from agriculture and allied activities in Rs. '000/ha of net sown area in TE 2015-16 (in 2011-12 prices). Source CSO and DES 


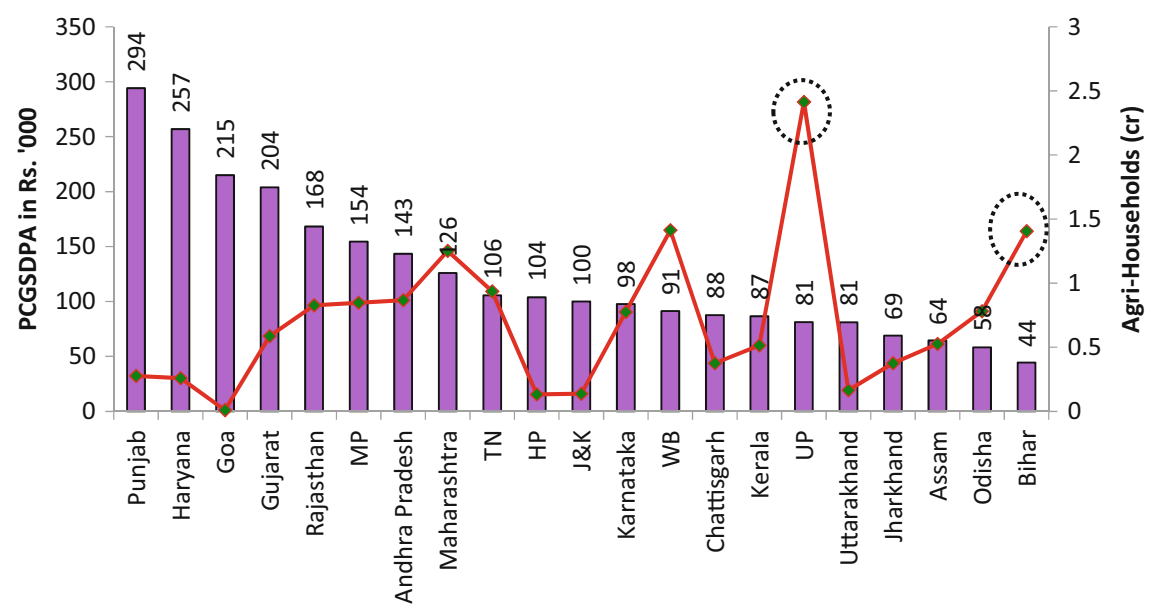

$\square$ PCGSDPA in Rs. '000 $\rightarrow$ Agri Households in 2012-13 (crore)

Fig. 3.4 State-wise per capita gross state domestic product (in Rs. '000) from agriculture and allied activities in 2016-17. Source CSO and CENSUS

crops in Tamil Nadu; spices and fisheries in Kerala, fisheries and vegetables in West Bengal) perform better in terms of GVO, but their input costs are also very high.

In terms of PCGSDP (GSDP from agriculture per agricultural household) Punjab, Haryana and Gujarat appear to be the wealthiest states. Punjab's PCGSDPA is almost 7 times higher than the poorest state Bihar, indicating wide disparities. Variations in the population growth rate of different states also lead to variation in the per capita GSDPA. States like Bihar and Uttar Pradesh with very high population growth rates fare poorly in terms of this indicator (Fig. 3.4).

Green revolution strategies to augment food grain production were implemented in some parts of the country (Punjab, Haryana and western UP) in the 1960s in a holistic manner and cereal production increased manifold in these areas. The remarkable performance was the result of new farm technology in the form of a combination of high-yielding variety of seeds, fertilisers and pesticides and irrigation infrastructure, which transformed the agrarian structure of these states completely. It resulted in concentrated high growth in the north-western part of India. But eastern states are still dependent on rainfall, making output subject to volatility. The spatial variation in agriculture still exists decades after the implementation of the green revolution; some states show above-average growth rates while others have lagged behind. However, it is important to note that in the initial years of development, very small incentives can boost production substantially (say as in MP, Bihar), but after reaching a high growth trajectory, when their level becomes high, it becomes difficult to boost growth rates further (as in Punjab, Haryana). This is discussed in detail in the state chapters.

Since the green revolution, Indian agriculture specialised in the production of cereals, which have reached a saturation point. Given the limited GCA, the main 
Table 3.1 Productivity of important crops

\begin{tabular}{l|l|l|l}
\hline $\begin{array}{l}\text { Productivity } \\
\text { (MT/ha) }\end{array}$ & TE 1992-93 & TE 2002-03 & TE 2016-17 \\
\hline Rice & 1.70 & 2.00 & 2.40 \\
\hline Wheat & 2.33 & 2.70 & 3.00 \\
\hline Maize & 1.50 & 1.80 & 2.60 \\
\hline Cereals & 1.60 & 1.90 & 2.40 \\
\hline Pulses & 0.53 & 0.57 & 0.72 \\
\hline
\end{tabular}

Source Directorate of Economics and Statistics

challenge Indian agriculture faces is low productivity (Table 3.1). The yields of inputintensive (water, fertiliser, power) products like rice and wheat are much lower than in China (Economic Survey 2015-16). ${ }^{4}$ Even though India is the largest producer and consumer of pulses, its productivity is lower than those of other major world producers of pulses. ${ }^{5}$ Hence, there is scope to increase productivity further.

However, in the last few years, it has become apparent that raising production without a harmonised market structure is likely to be counter-productive. In times of glut, the prices of many commodities fall much below their respective MSPs and drop to levels that make it impossible to even recover the full cost (C2) of production, leading to farmers' agitations in different parts of the country. Although agriculture's share in total GSDP declined to around 17\% (in current prices) in 201617 , the movement of labour out of agriculture has been very slow and, according to the Labour Bureau 2015-16, $47 \%$ of the total workforce is still employed in agriculture. The share is as high as $74 \%$ in Chhattisgarh, 57\% in Andhra Pradesh, 55\% in Madhya Pradesh and 54\% in Bihar. It is lowest in Punjab (34.1\%), Kerala (22.3\%) and Himachal Pradesh (20.9\%). Even though non-farm employment plays an important role in poverty reduction, especially in urban areas, agriculture still plays a critical role. Studies have shown that agricultural growth often results in faster poverty reduction and improvement in nutritional status as compared to similar growth levels in other sectors (WDR 2008).

\subsection{Poverty and Malnutrition Situation in India}

Poverty levels in India have been exceptionally high, particularly until 1993-94. Half of the population in rural India was living below the poverty line in 1993-94. However, high economic growth and sustained government efforts and programmes have delivered and helped alleviate poverty in the country. As a result, the poverty

\footnotetext{
${ }^{4}$ According to FAO data, productivity of paddy (rice) in China is $6.9 \mathrm{MT} / \mathrm{ha}$ as against $3.8 \mathrm{MT} / \mathrm{ha}$ in India in 2017.

${ }^{5}$ According to FAO data, productivity of pulses in major exporting states are as follows: Canada (2.0 MT/ha), Australia (1.8 MT/ha), USA (1.5 MT/ha) in 2017. For TE 2016-17, India's productivity of pulses was $0.72 \mathrm{MT} / \mathrm{ha}$.
} 
headcount ratio has declined significantly in the past two decades both in rural and urban India (Fig. 3.5). The overall HCR poverty has fallen by a little more than half from $45.3 \%$ in $1993-94$ to $21.9 \%$ by $2011-12$.

In terms of malnutrition, India's estimates have been high and sticky for a long time (1998-99 to 2005-06). However, there has been considerable improvement in recent years (NFHS-4, 2015-16). Despite the progress, the existing level of child malnutrition (Fig. 3.6) is still very high in absolute terms; there is also considerable inter-state variation. Any improvement in the country's/household's situation will have its initial impact on mortality rates. The infant mortality rate fell from 68 to 57 deaths per 1000 live births between 1998-99 and 2005-06, then again declined to 41 deaths per 1000 live births by 2015-16. So, the risk of mortality was reduced in the first time period (1998-99 to 2005-06), though there was not much change in

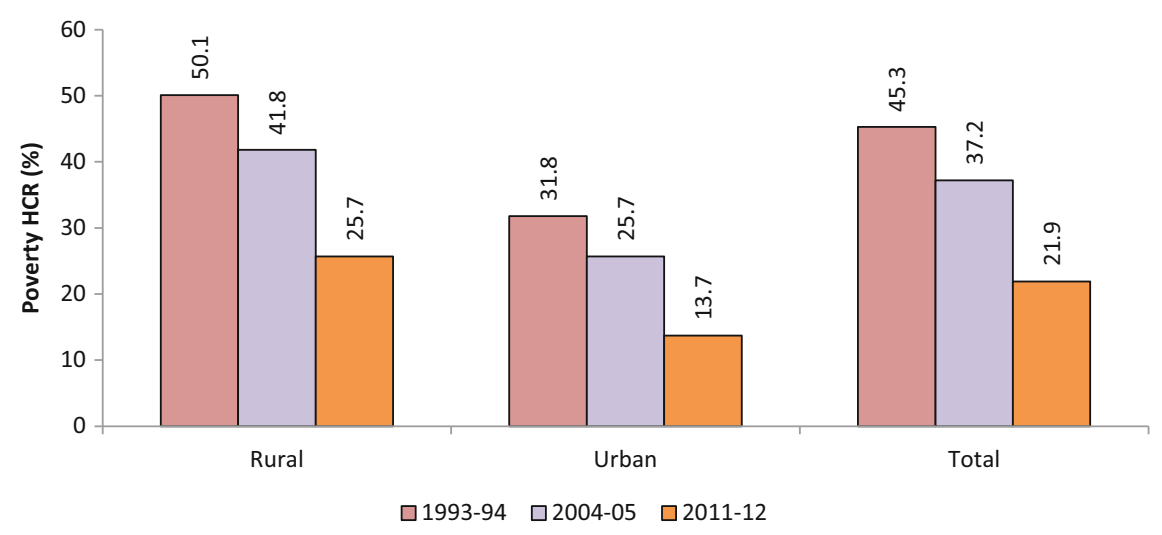

Fig. 3.5 Head count ratio (HCR) of poor (poor as a percentage of population) based on Tendulkar methodology. Source Planning Commission, Report of the Expert Group to Review the Methodology for Measurement of Poverty, 2014

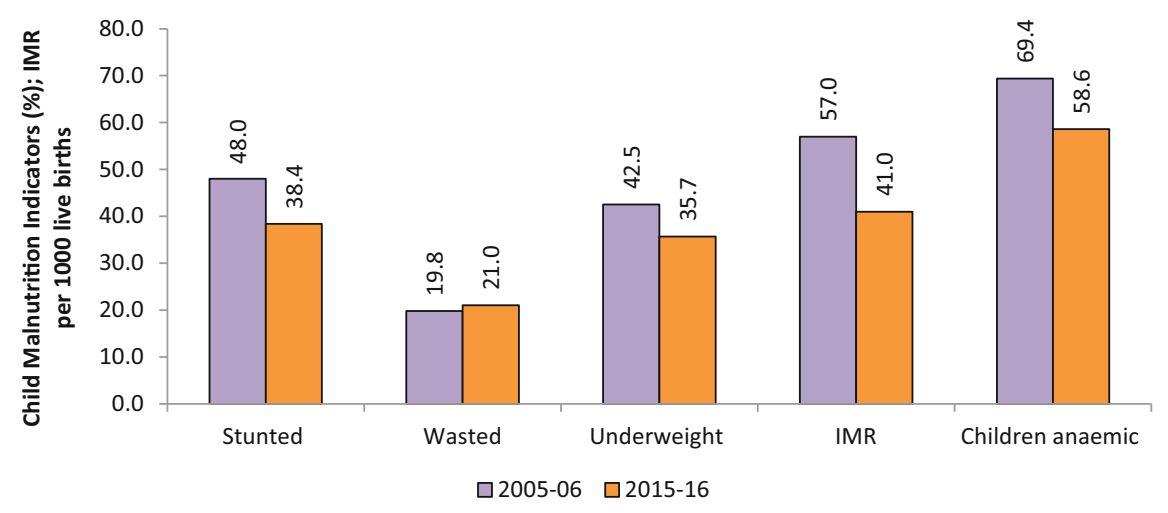

Fig. 3.6 Situation of child malnutrition in India. Source NFHS 3 and 4 


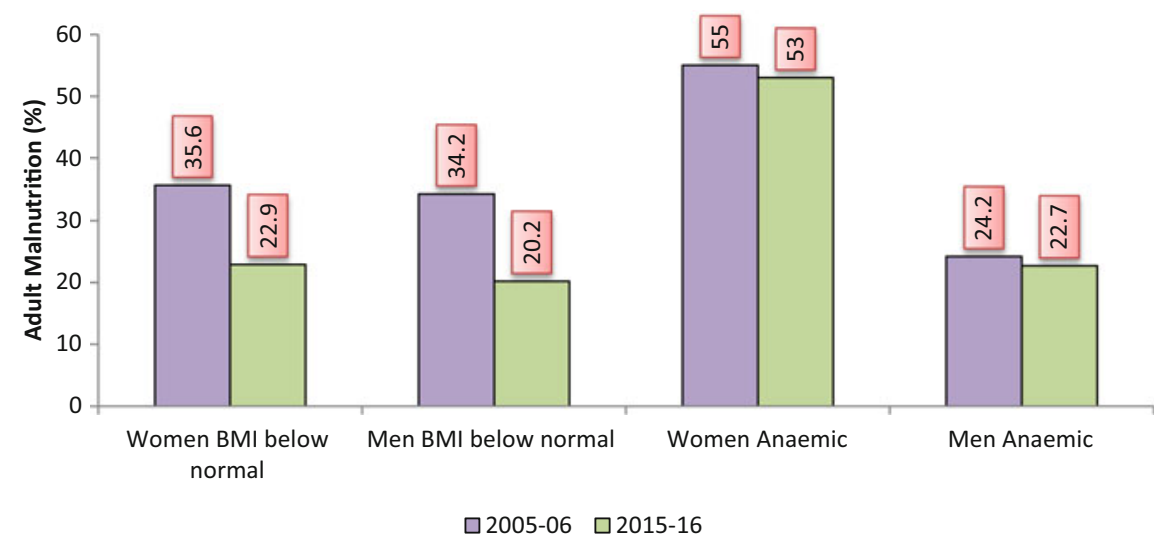

Fig. 3.7 Adult malnutrition in India. Source NFHS 3 and 4

terms of a reduction of the risk of malnutrition. But in the next period (2005-06 to 2015-16), the risk of malnutrition fell significantly, although there is still a long way to go. Maybe it is indicative of long lags between the reduction in mortality rates and its effects on malnutrition. There has been a steady decline in the percentage of stunted (48 to $38.4 \%$ ) and underweight children (42.5 to 35.7\%) (Fig. 3.6).However, there was a marginal increase in the share of wasted children (19.8 to $21 \%$ ), which requires further investigation. The Rapid Survey on Children (RSOC) data estimates the proportion of wasted children for the year 2013-14 at only $15.1 \%$, which is lower than the NFHS figure of $21 \%$ in 2015-16. Maybe future NFHSs will reveal a different picture with respect to wasting of children too. Notwithstanding all this, it is somewhat worrisome that more than half $(58.4 \%)$ of India's children under five years of age suffer from anaemia.

Adult malnutrition is higher among women compared to men aged 15 to 49 years (Fig. 3.7). In 2005-06, 35.6\% of women and 34.2\% of men were classified as thin with a body mass index less than $18.5 \mathrm{~kg} / \mathrm{m}^{2}$. In 2015-16, the share declined to 23 and $20 \%$ for women and men aged 15 to 49 years respectively. This is a significant improvement. But there has not been any commensurate improvement in the micronutrient deficiency among adults. The percentage of women and men suffering from anaemia for the year 2015-16 was 53\% and 23\%, respectively. The corresponding figures were $55 \%$ and $24 \%$ respectively in $2005-06$. The fact that the rate of anaemic women is more than double that of men is a matter of concern and requires a serious discussion about gender discrimination in Indian diets at the household level. And this should get a special push at the policy level too. Anaemia in women has an adverse effect on children's nutrition levels as well.

There is rural-urban disparity in the indicators of malnutrition. In rural India, the prevalence of stunted and underweight children is $41 \%$ and $38 \%$, which is high compared to the urban figures of $31 \%$ and $29 \%$ respectively. Similarly, $27 \%$ of 


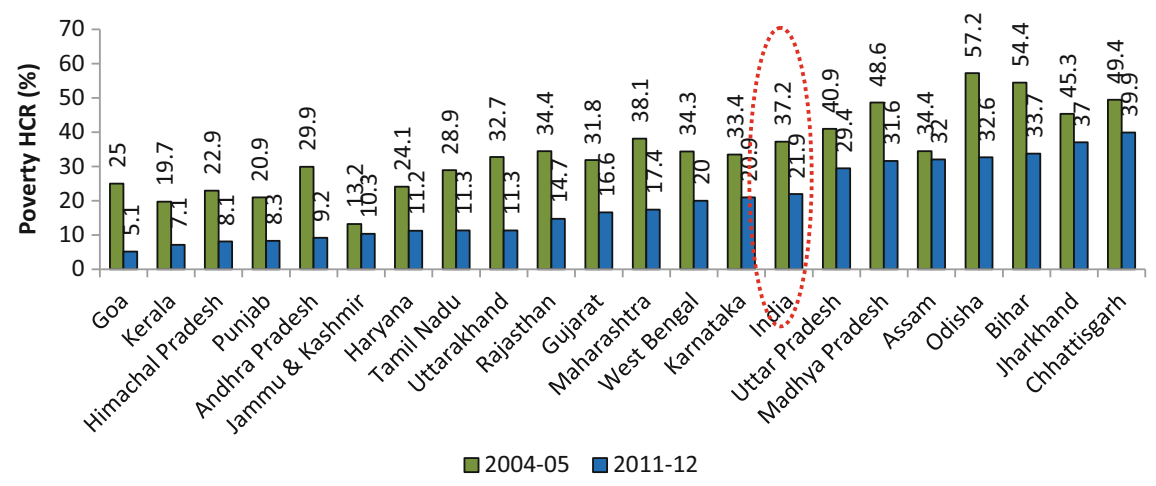

Fig. 3.8 State-wise poverty head count ratio, 2004-05 and 2011-12. Source Planning Commission, Report of the Expert Group to Review the Methodology for Measurement of Poverty, 2014

women and $23 \%$ of men had below normal BMI in rural India in 2015-16, compared to $15.5 \%$ and $15.3 \%$ in urban India respectively.

However, as is the case with any national average, this too masks wide inter-state and intra-state variations.

\subsubsection{State-Wise Variation in Poverty}

State-wise poverty headcount ratios for the year 2011-12 shows that there exists wide spatial variation across states. States like Kerala, Himachal Pradesh and Punjab (that also perform well in agriculture) have a lower number of people below poverty line (BPL) compared to other states. On the other hand, Chhattisgarh, Jharkhand and Bihar perform poorly in terms of poverty (Fig. 3.8).

\subsubsection{State-Wise Variation in Child and Adult Malnutrition}

State-wise nutrition parameters indicate a huge spatial variation in malnutrition and micronutrient deficiency. The indicators of child under-nutrition are the percentage of stunted, wasted and underweight children under 5 years of age. Each of these indicators represents different aspects of child malnutrition. Stunting is indicative of prolonged under-nutrition while wasting indicates current nutritional status determined by food intake and/or illness. Underweight indicates both acute and chronic malnutrition.

Bihar, Uttar Pradesh and Jharkhand fare poorly in anthropometric indicators. The percentage of undernourished children in these states is more than double when 
compared to the best performing states of Kerala, Himachal Pradesh, Jammu and Kashmir and Punjab.

The adult nutrition situation is somewhat better across states. But it is still a long journey for states like Jharkhand, Bihar, Madhya Pradesh and Gujarat with 31.5, $30.4,28.4$ and $27.2 \%$ of thin women (BMI < 18.5) and 23.1, 25.4, 28.4 and $24.7 \%$ of thin men, respectively (BMI < 18.5) in 2015-16.

In 2005-06, half or more than half the population of children below 5 years were stunted in the six states of Uttar Pradesh, Bihar, Chhattisgarh, Gujarat, Madhya Pradesh and Jharkhand. By 2015-16, none of the states was in that category (Fig. 3.9). The highest share of stunted children is now in Bihar (48.3\%). Among the states, the fastest decline of stunting (shown as a black line in Fig. 3.9) was observed in Chhattisgarh (a decline of more than 15\%), followed by Gujarat ( $-13.2 \%)$, Himachal Pradesh $(-12.3 \%)$ and West Bengal $(-12.1 \%)$.

In terms of percentage of children below five years who suffer from wasting (i.e. low weight for height), the situation, nationally and for most states, has worsened. At the all-India level, this percentage has increased from 19.8 to $21 \%$. Interestingly, on all other major indicators of child malnutrition, the situation has improved, except for this indicator where the situation has worsened between 2005-06 and 2015-16 (Fig. 3.10).

Among the 21 states for which the data has been presented above, it shows worsened levels of wasting in children between 2005-06 and 2015-16 in 15 states. Maharashtra shows the worst performance between these years with the incidence of wasting having increased from 16.5 to $25.6 \%$ between $2005-06$ and 2015-16. This means that at least one in every four children in Maharashtra state has low weight for height, i.e. they suffer from wasting. The states of Madhya Pradesh $(-9.2 \%)$, Bihar $(-6.3 \%)$ and Himachal Pradesh $(-5.6 \%)$ showed the fastest decline in this indicator.

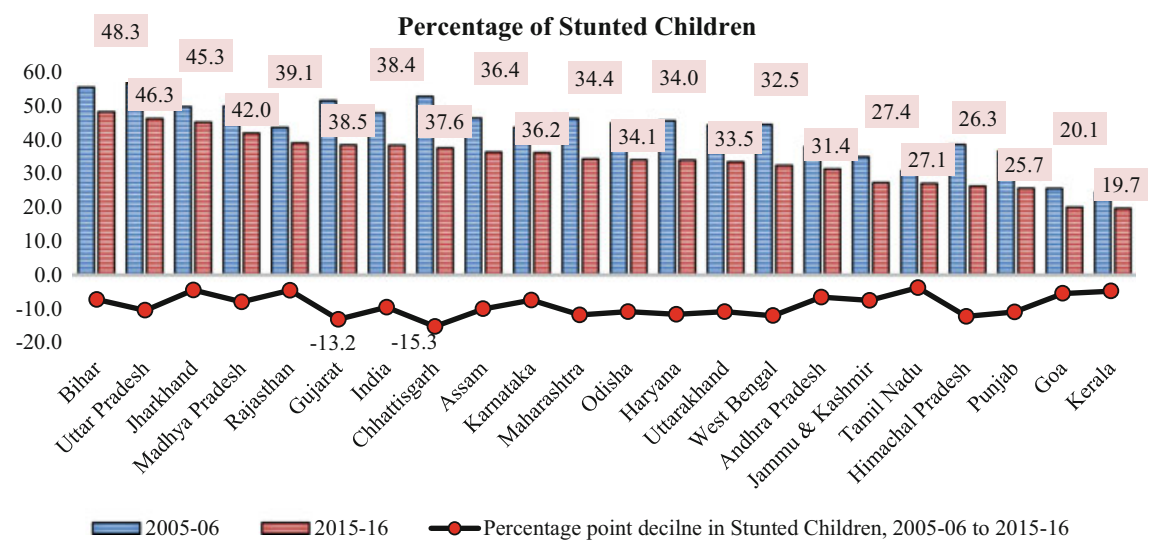

Fig. 3.9 Percentage of stunted children across states, 2005-06 and 2015-16. Source Based on data from various rounds of NFHS 


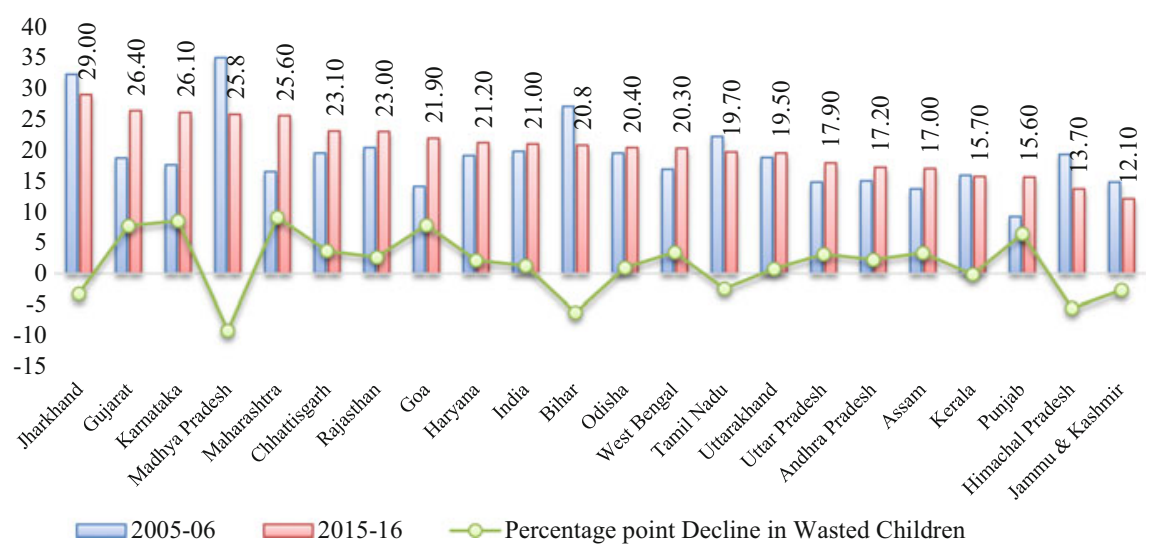

Fig. 3.10 Percentage of wasted children across states, 2005-06 and 2015-16. Source NFHS 3 and 4

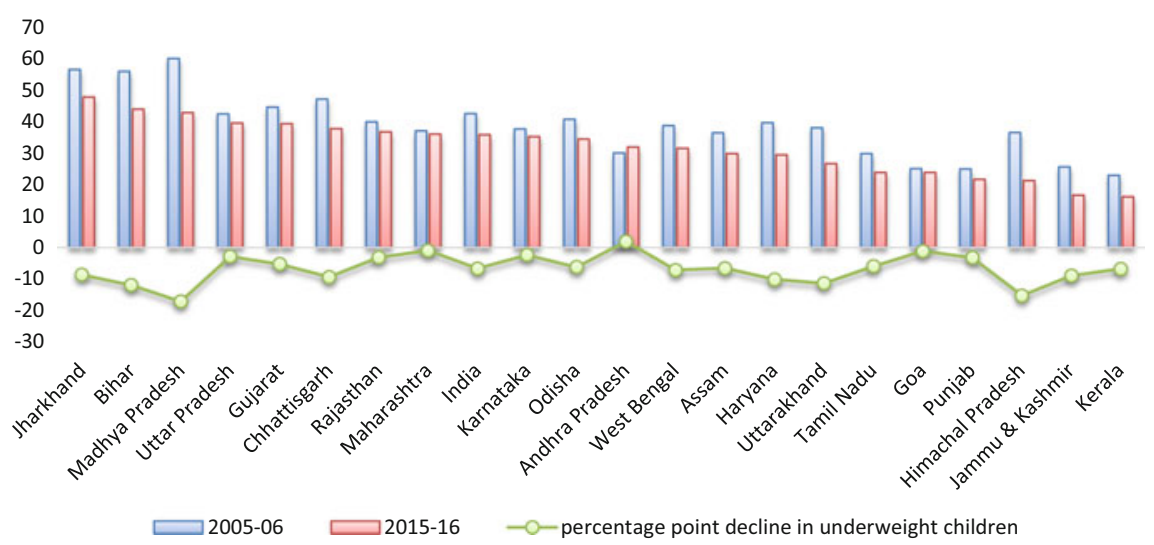

Fig. 3.11 Percentage of underweight children across states, 2005-06 and 2015-16. Source NFHS 3 and 4

In terms of the proportion of children who were underweight (Fig. 3.11), the situation has improved in all states. The only exception was Andhra Pradesh where the percentage of children who are underweight increased from 30 to $31.9 \%{ }^{6}$

In terms of nutrition indicators for adults, the situation has improved in all states (Figs 3.12 and 3.13).

State-Wise Performance of the Agricultural Sector and Malnutrition Indicators

\footnotetext{
${ }^{6}$ Andhra Pradesh data for child malnutrition corresponds to children below age 3 .
} 


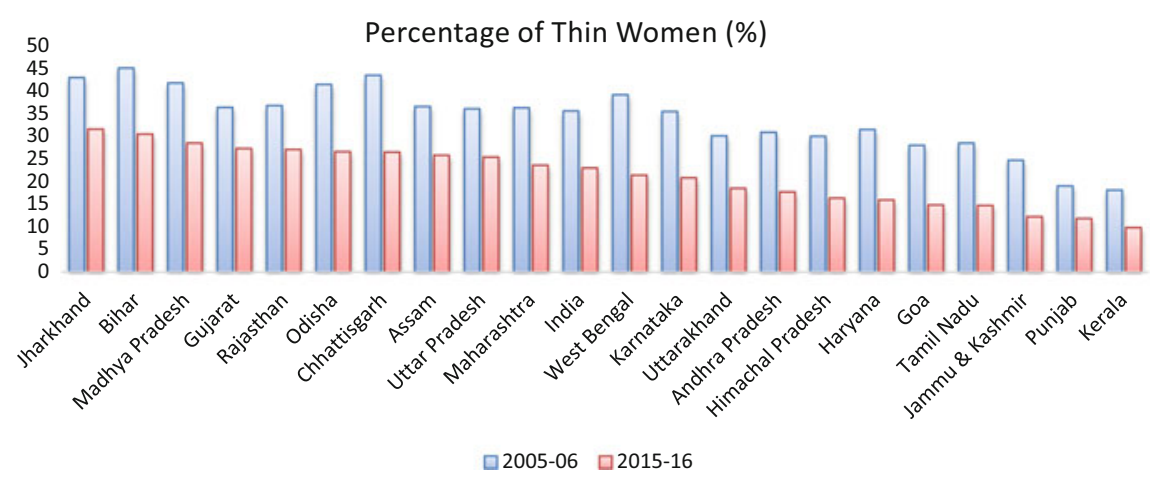

Fig. 3.12 Percentage of thin women across states, 2005-06 and 2015-16

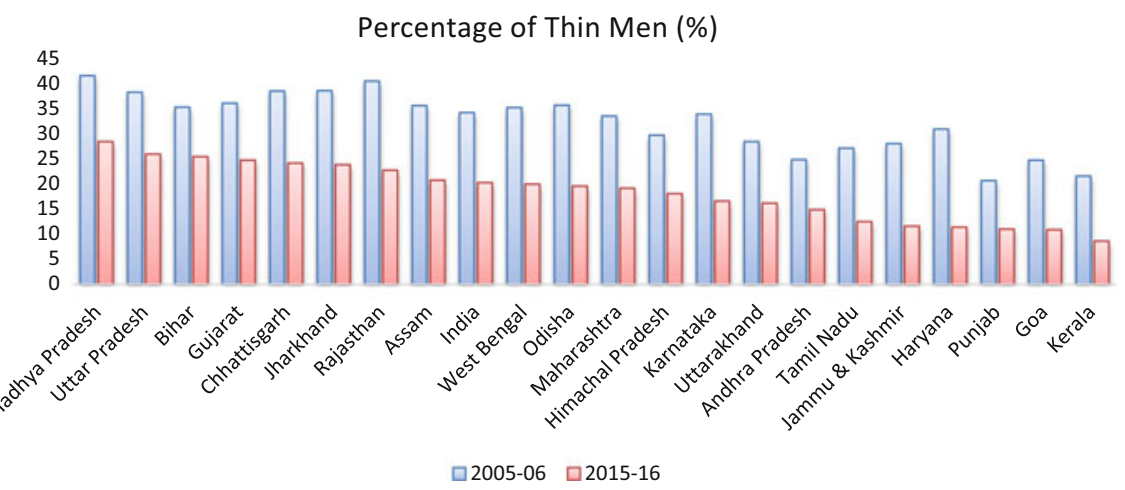

Fig. 3.13 Percentage of thin men across states, 2005-06 and 2015-16. Source NFHS, 2005-06 and $2015-16$

If we were to map the performance of states on the three indicators of child malnutrition with the agricultural GDP growth rates in states (Fig. 3.14), we find interesting trends. In the figure below, we present the trends for the six focal states.

Three things, inter alia, emerge from the above figure:

1. Among the six states, MP's agricultural GDP grew the fastest and that seems to have translated into significantly improved child malnutrition indicators.

2. Except for Madhya Pradesh and Bihar, all the focal states have experienced an increase in the level of wasting irrespective of their agricultural performance.

3. More generally, agricultural GDP performance appears more closely associated with a state's performance on its "underweight" indicator. ${ }^{7}$

\footnotetext{
${ }^{7}$ Based on simple correlation between the malnutrition indicators and agricultural GDP growth rates.
} 


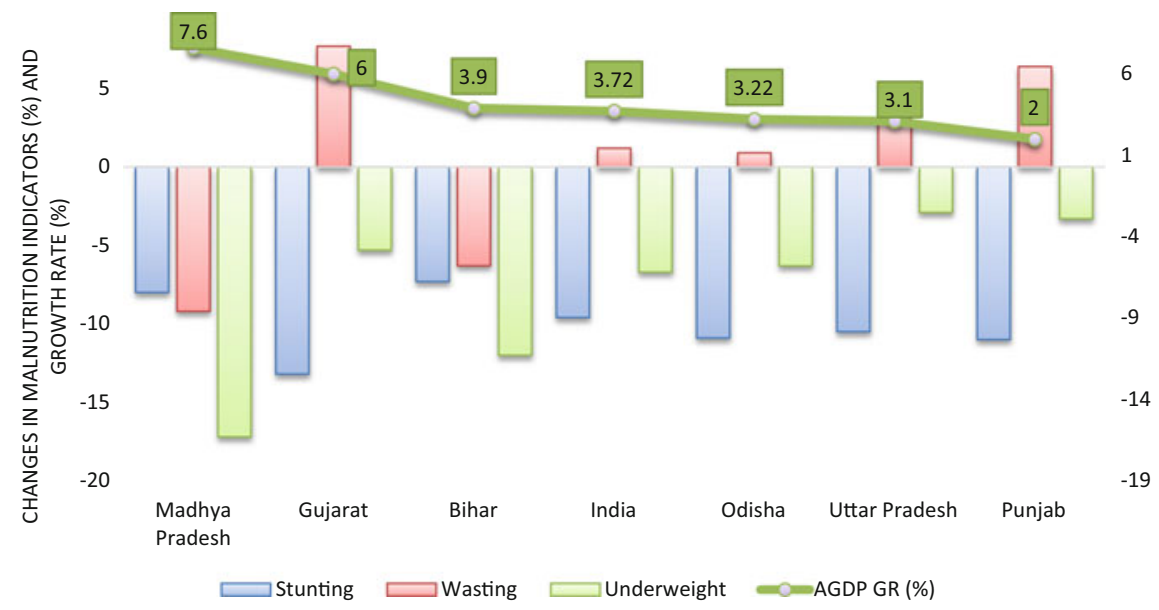

Fig. 3.14 Mapping changes in malnutrition indicators and agricultural GDP growth rates. Source Data taken from various rounds of NFHS and MOSPI. Note The malnutrition indicator data presented above are calculated as the difference between the actual value of the indicator between 2005-06 and 2015-16. The agricultural GDP growth rate (or AGDP GR) data is calculated as the average agricultural GDP growth in the state between 2005-06 and 2017-18

So, what does this imply? To answer that, one needs to assess if the relation between agricultural performance and performance on various malnutrition indicators is as linear as the figure makes it out to be. To provide depth and robustness to the dynamics of this relation, we undertake an econometric exercise presented in the next section.

\subsection{Linkages Between Agriculture, Poverty and Malnutrition}

\subsubsection{Linkages between Agriculture and Poverty}

For a long time, poverty has been concentrated in the rural parts of India. There have been many studies that explain the direct linkage between poverty and agriculture (World Development Report 2008; Godoy 2010). There are many ways agricultural growth can lead to the betterment of a country's population. First, improved agriculture can directly result in increased farm income. Second, the availability of cheaper food will have a positive effect on nutrition. Third, agriculture creates an opportunity for the non-farm sector as well (World Development Report 2008; Godoy 2010). The correlation between poverty and factors that could affect poverty are reported in Table 3.10 in the Annexure . Agricultural performance (PCGSDP), non-farm employment (NFemp), literacy (Lit) and infrastructure (surfaced road density) have a significant 
negative relation with poverty. The relationship between agriculture and poverty has been investigated through an estimate based on a panel data random-effects model (the Hausman test result confirms random-effects) with poverty being the dependent variable and the factors mentioned above as the explanatory variables with data for 21 major states pooled for two years (2004-05 and 2011-12). There is a strong correlation among the explanatory variables (literacy and infrastructure, non-farm employment and infrastructure, non-farm employment and literacy) and no scope for using instrumental variables. Hence, we have chosen three separate models based on the overall significance of the regression equations. All variables are in the log form; hence coefficients indicate elasticity.

With a structural change in the economy, non-farm employment turned out to be the most important variable influencing poverty, but agricultural income still plays an important role (Table 3.2). Given the declining average holding size in agriculture (1.08 ha in 2015-16), it seems only rational for people engaged in agriculture to look for non-farm incomes supplementing their agricultural incomes. There is ample evidence from NSSO surveys that the smaller the holding size, the more the proportion of income coming from wages and salaries other than from the cultivation of crops. This is taken up in detail in a later chapter on Doubling Farmers' Income. Other important variables that show a strong relationship with poverty are literacy and surfaced road density. Road infrastructure has also been found very powerful in reducing poverty, especially in studies done at IFPRI (Fan et al. 2007).

Table 3.2 Regression results: poverty and factors affecting poverty

\begin{tabular}{|c|c|c|c|}
\hline Independent variable & Poverty HCR & Poverty HCR & Poverty HCR \\
\hline $\begin{array}{l}\text { PCGSDPA } \\
\text { (Standard deviation) }\end{array}$ & $\begin{array}{l}-0.73 * * * \\
(0.19)\end{array}$ & $\begin{array}{l}-0.74 * * \\
(0.25)\end{array}$ & $\begin{array}{l}-0.89 * * * \\
(0.23)\end{array}$ \\
\hline $\begin{array}{l}\text { Non-farm employment } \\
\text { (Standard deviation) }\end{array}$ & $\begin{array}{l}-1.39 * * * \\
(0.28)\end{array}$ & & \\
\hline $\begin{array}{l}\text { Literacy } \\
\text { (Standard deviation) }\end{array}$ & & $\begin{array}{l}-1.97 * * \\
(-0.70)\end{array}$ & \\
\hline $\begin{array}{l}\text { Surfaced road density } \\
\text { (Standard deviation) }\end{array}$ & & & $\begin{array}{l}-0.27 * * \\
(0.09)\end{array}$ \\
\hline $\begin{array}{l}\text { Constant } \\
\text { (Standard deviation) }\end{array}$ & $\begin{array}{l}11.57 * * * \\
(1.09)\end{array}$ & $\begin{array}{l}14.58^{* * * *} \\
(2.64)\end{array}$ & $\begin{array}{l}6.60 * * * \\
(0.95)\end{array}$ \\
\hline Number of observation & 42 & 42 & 42 \\
\hline$R$ square within & 0.56 & 0.47 & 0.47 \\
\hline$R$ square between & 0.69 & 0.53 & 0.53 \\
\hline$R$ square overall & 0.61 & 0.47 & 0.48 \\
\hline
\end{tabular}

Source Authors calculation

Note $* *$ significant at $5 \%, * * *$ significant at $1 \%$ (Definition and construction of variables are given in detain in Annexure Table 3.9). Numbers in parentheses are standard deviations 


\subsubsection{Linkages Between Agriculture and Malnutrition}

In this section, we have taken one representative variable from each dimension (income, literacy, child care, access to health care and household amenities) to measure the interplay of malnutrition and socio-economic variables. Adult malnutrition is measured by taking a simple average of the share of thin men and women $\left(\mathrm{BMI}<18.5 \mathrm{~kg} / \mathrm{m}^{2}\right)$. Tables 3.3 and 3.4 show that gross value of output per hectare of gross cropped area (measuring the performance of agriculture) has a higher standard deviation than other independent variables indicating a large variation across states. To explain child malnutrition, three important indicators have been considered: IMR per 1000 live births, share of stunted children below the age of 5 years at the state level and underweight children below the age of 5 years at the state level. Detailed description of the variables and their respective sources are presented in Table 3.9 in Annexure. Table 3.4 shows IMR has higher standard deviation, compared to the percentage of underweight and stunted children. This is expected as any positive change in the socio-economic status of the household will have its initial impact on

Table 3.3 Summary statistics: adult malnutrition

\begin{tabular}{l|l|c|c|l|l}
\hline Variable & Observations & Mean & Standard deviation & Min. & Max. \\
\hline BMI & 42 & 26.5 & 9.3 & 9.1 & 41.65 \\
\hline GVOA/ha & 42 & 585.1 & 265.9 & 203 & 1215 \\
\hline Flit & 42 & 66.3 & 15.12 & 36.2 & 97.9 \\
\hline Mlit & 42 & 75.3 & 16.7 & 36.2 & 98.1 \\
\hline HH_Toilet & 42 & 50.5 & 20.8 & 15.1 & 98.1 \\
\hline Delivery_HP & 42 & 68.7 & 22.9 & 27.2 & 100 \\
\hline
\end{tabular}

Source Data taken from various rounds of NFHS and MOSPI

Table 3.4 Summary statistics: child malnutrition

\begin{tabular}{l|l|l|l|l|l}
\hline & Observations & Mean & Standard deviation & Min & Max \\
\hline IMR & 42 & 42.5 & 16.9 & 6 & 72.7 \\
\hline Stunted & 42 & 38 & 9.5 & 19.7 & 56.8 \\
\hline Underweight & 42 & 35.2 & 10.1 & 16.1 & 60 \\
\hline GVOA/ha & 42 & 585.1 & 265.9 & 203 & 1215 \\
\hline Flit & 42 & 65.3 & 15.1 & 36.2 & 97.9 \\
\hline HH_Toilet & 42 & 50.5 & 20.8 & 15.1 & 98.1 \\
\hline Bfed_1 h & 42 & 38.9 & 17.7 & 3.7 & 73.3 \\
\hline Delivery_HP & 42 & 68.9 & 22.9 & 27.2 & 100 \\
\hline Vaccination & 42 & 59.9 & 16.6 & 23 & 89.1 \\
\hline
\end{tabular}

Source Data taken from various rounds of NFHS and MOSPI 
infant mortality. In the period between 2005-06 and 2015-16, there has been a major decline in infant mortality rates in all states.

Factors affecting child malnutrition also vary across states. Although we have taken the same explanatory variables to explain the dependent variables, the degree and nature of the association are different.

\section{Interpretation of the Regression Results}

The present analysis is based on panel data on malnutrition and factors affecting it collected for two points of time, 2005-06 and 2015-16, across 21 major states. The correlation between child and adult malnutrition and the factors that could affect them are presented in the Annexure Tables 3.11 and 3.12. As expected, agricultural performance shows a high and negative correlation with malnutrition. Other important factors significantly influencing malnutrition are literacy, toilet facilities at home, access to health care facilities (vaccination, delivery by health personnel) and child feeding practices (breastfed within an hour of birth).

Many of these explanatory variables show a high correlation with each other. For example, there is a very high correlation between literacy and toilet facilities. Literacy is also highly correlated with child vaccination and child care. This kind of collinearity suggests that the estimation procedure should be based on the instrumental variable approach. However, dearth of data prevents us from using this approach. As far as possible, we have used different combinations of explanatory variables that are not expected to suffer from endogeneity.

Our analysis is based on panel data (both time and state dummies) fixed and random effect models to investigate the interplay of malnutrition and the factors that affect it. The fixed effect model is used while analysing the impact of variables that vary over time. The rationale behind the random effect model is that the variation across entities is assumed to be random and uncorrelated with the predictor or independent variables in the model. The Hausman test has been run to choose between fixed effect model and random effect model. The Hausman test confirms that the fixed effect model is appropriate to examine the relationship between IMR with agriculture, access to health variables. However, the random effect model is preferred for the other three equations. We have chosen four models based on the overall significance of the coefficients of the regressors.

To investigate the association between agricultural performance and adult malnutrition, we estimate a random-effects model with BMI (average of percentage of men and women BMI below normal) as the dependent variable and factors mentioned above as the independent variables. Factors that have a significant influence on adult malnutrition are agricultural performance, literacy and delivery assisted by health personnel (Table 3.5). Sanitation and access to improved water are also important variables. But female literacy is highly correlated with access to toilet and health care and child feeding practices and hence, cannot be measured in the same equation.

Similarly, the association between agricultural performance and child malnutrition is estimated using the fixed effects model with IMR as the dependent variable and random-effects model with stunted and underweight as dependent variables (depending on the results of the Hausman test). Agricultural performance holds a 
Table 3.5 Association of BMI with agriculture, access to health and sanitation variables (random effect model)

\begin{tabular}{l|l}
\hline Dependent variable & BMI \\
\hline Independent variables & \\
\hline GVOA/ha & $-0.05^{* * *}$ \\
Standard deviation & $(0.008)$ \\
Elasticity & -0.21 \\
\hline Total_Lit & $-0.35^{* *}$ \\
Standard deviation & $(0.13)$ \\
Elasticity & -0.99 \\
\hline Delivery_HP & $-0.10^{* * *}$ \\
Standard deviation & $(0.04)$ \\
Elasticity & -0.26 \\
\hline Constant & $65.9 * * *$ \\
Standard deviation & $(7.58)$ \\
\hline Number of Observations & 42 \\
\hline$R$ square within ${ }^{\mathrm{a}}$ & 0.95 \\
\hline$R$ square between & 0.59 \\
\hline$R$ square overall & 0.79
\end{tabular}

Source Authors calculation

Note $* *$ significant at $5 \%, * * *$ significant at $1 \%$ (Definition and construction of variables are given in detain in Annexure Table 3.9). Numbers in parentheses are standard deviations

${ }^{a}$ Within $R$-square measures, how much variation over time is explained and between $R$-square measures, how much variation across cross-section is explained; overall $R$ square measures overall variation in the data

strong negative relation with child malnutrition. Access to improved sanitation facilities (toilet facilities and drinking water) has a strong impact on long-term child malnutrition indicators (stunted and underweight children). Other important factors affecting child malnutrition are vaccination (percentage of children in the age group 12-23 months who received all basic vaccinations: BCG, measles, three doses each of DPT and polio vaccines), delivery assisted by health personnel and breastfeeding practices (Tables 3.6, 3.7 and 3.8).

\subsection{Performance of Socio-Economic Factors Affecting Malnutrition}

In this section, we have followed international literature (UNICEF 2013; Gulati et al. 2012; Bhagowaliya 2012; Kadiyala 2014) as well as results derived from the above analysis to construct a conceptual framework of malnutrition, which is greatly influenced by the agricultural performance of the state/country. Other immediate 
Table 3.6 Association of IMR with agriculture, access to health variables (fixed effect model)

\begin{tabular}{l|l}
\hline Dependent variable & IMR \\
\hline Independent variables & \\
\hline GVOA/ha (gross value of agriculture per ha of GCA) & $-0.03^{* *}$ \\
Standard deviation & $(0.01)$ \\
Elasticity & -0.08 \\
\hline Vaccination (children having all basic vaccination) & $-0.23^{* *}$ \\
Standard deviation & $(0.11)$ \\
Elasticity & -0.331 \\
\hline Delivery_HP & $-0.24 * * *$ \\
Standard deviation & $(0.08)$ \\
Elasticity & -0.39 \\
\hline Constant & $76.5 * * *$ \\
Standard deviation & $(4.28)$ \\
\hline Number of observations & 42 \\
\hline$R$ square within & 0.89 \\
\hline$R$ square between & 0.84 \\
\hline$R$ square overall & 0.77 \\
\hline$S$ S &
\end{tabular}

Source Authors calculation

Note $* *$ significant at $5 \%, * * *$ significant at $1 \%$. Numbers in parentheses are standard deviations

Table 3.7 Association of stunting with agriculture, access to housing amenities and health variables (random effect model)

\begin{tabular}{l|l}
\hline Dependent variable & Stunted \\
\hline Independent variables & \\
\hline GVOA/ha & $-0.03^{* *}$ \\
Standard deviation & $(0.009)$ \\
Elasticity & 0.08 \\
\hline HH_toilet & $-0.18^{* * *}$ \\
Standard deviation & $(0.04)$ \\
Elasticity & 0.23 \\
\hline Vaccination & $-0.25^{* * *}$ \\
Standard deviation & $(0.05)$ \\
Elasticity & 0.39 \\
\hline Constant & $66.6^{* * *}$ \\
Standard deviation & $(2.79)$ \\
\hline Number of observations & 42 \\
\hline$R$ square within & 0.73 \\
\hline$R$ square between & 0.84 \\
\hline$R$ square overall & 0.81 \\
\hline$S$ Sce Aurs &
\end{tabular}

Source Authors calculation

Note $* *$ significant at $5 \%$, ***significant at $1 \%$. Number in parentheses are standard deviations 
Table 3.8 Association of being underweight with agriculture, access to housing amenities and health variables (random effect model)

\begin{tabular}{l|l}
\hline Dependent variable & Underweight \\
\hline Independent variables & \\
\hline GVOA/ha & $-0.03^{* *}$ \\
Standard deviation & $(0.01)$ \\
Elasticity & -0.08 \\
\hline HH_toilet & $-0.25^{* * *}$ \\
Standard deviation & $(0.05)$ \\
Elasticity & -0.36 \\
\hline Bfed_1hr (\% of children who are breastfed within an hour) & $-0.14^{* *}$ \\
Standard deviation & $(0.06)$ \\
Elasticity & -0.15 \\
\hline Constant & $56.04^{* * *}$ \\
Standard deviation & $(3.05)$ \\
\hline Number of observations & 42 \\
\hline$R$ square within & 0.63 \\
\hline$R$ square between & 0.71 \\
\hline$R$ square overall & 0.69 \\
\hline
\end{tabular}

Source Authors calculation

Note $* *$ significant at $5 \%, * * *$ significant at $1 \%$. Numbers in parentheses are standard deviations

factors influencing child malnutrition are maternal and child care practices, household amenities and access to health facilities. In turn, these are influenced by female literacy, the structure of the economy, the political situation, societal arrangements, etc. Each factor affecting malnutrition is discussed briefly in the section.

\subsubsection{Women's Education}

Studies have shown that women's education and status in the family plays an important role in a child's nutrition. Literate mothers can make more efficient use of health care institutions (Borooah et al. 2002). Women make important decisions regarding family health, feeding and child care. Lack of knowledge can have an adverse effect on child health. To capture the impact of women's education, we have taken the gross enrolment ratio $^{8}$ for girls in I-VIII, gross enrolment ratio for girls in IX-X and gross enrolment ratio for girls XI-XII from the ministry of HRD for the year 2011-12 and female literacy rate for 2011. Each of these indicators of educational status is first

\footnotetext{
${ }^{8}$ Gross Enrolment Ratio (GER): Total enrolment at a specific level of education, regardless of age, expressed as a percentage of the eligible official school-age population corresponding to the same level of education in a given school-year. It is calculated by dividing the number of pupils (or students) enrolled in a given level of education regardless of age by the population of the age-group that corresponds to the given level of education, and multiplying the result by 100 .
} 


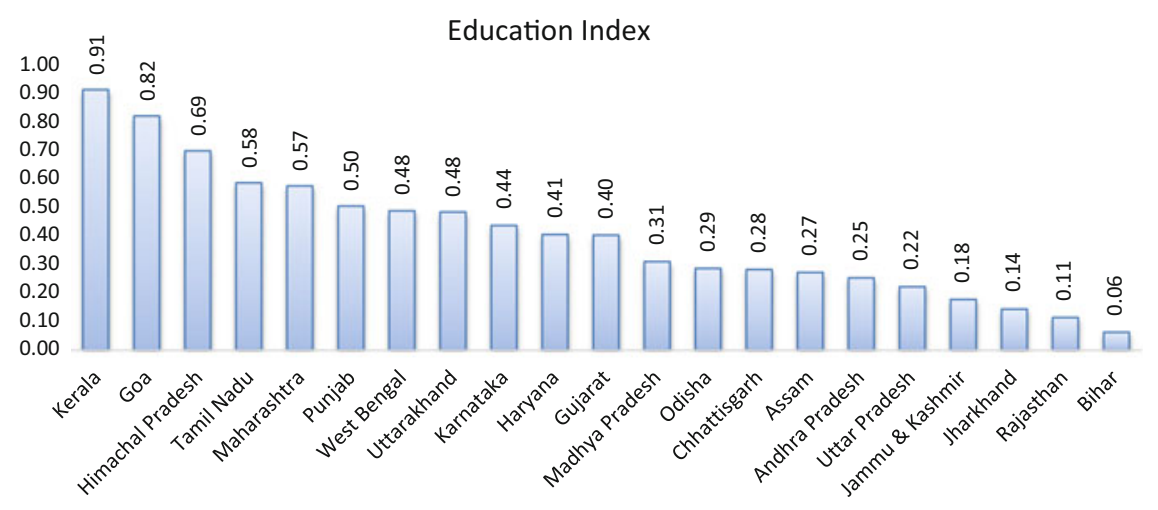

Fig. 3.15 Normalised education index. Source Ministry of HRD and NFHS-4

normalised according to the following formula:

$$
\text { Normalised Indicator }=\frac{\text { Actual Value }- \text { Minimum Value }}{\text { Maximum Value }- \text { Minimum Value }}
$$

And then a normalised education index is constructed by taking a weighted average of these indices with the one-third weight assigned to knowledge represented by the gross enrolment ratio and two-third assigned to adult literacy (Fig. 3.15).

States like Kerala, Himachal Pradesh, Tamil Nadu and Goa ranked high in the education index and Rajasthan, Bihar and Jharkhand fared badly in the ranking (Fig. 3.15).

\subsubsection{Child Care Practices}

In the case of malnutrition, an important underlying influence is the care provided to children. There has been increasing awareness of cultural and behavioural practices regarding child rearing that affects child nutrition. Inadequate care for children and women is one of the fundamental causes of malnutrition. Hygienic practices at home and in the handling of food and drinking water reduce the risk of illness. Care practice plays a vital role in the emotional as well as physical upbringing of children. The key care practices that affect child malnutrition include care of pregnant and lactating mothers, breastfeeding practices, feeding young children, care during illness, food preparation and hygiene (UNICEF 2013). ${ }^{9}$

\footnotetext{
${ }^{9}$ Care of pregnant women and hygiene have been analysed under dimensions of access to health facilities and household amenities (dimensions) respectively in the current study.
} 
Current evidence on feeding practices in India cited from the NFHS survey (201516) shows an improvement over NFHS-3 (2005-06) results. Early initiation of breastfeeding is highly recommended because it helps stimulate breast milk production. Breastfeeding within one hour ensures that the infant receives colostrum, which is rich in protective factors (WHO). The first breast milk is highly nutritious and has antibodies that protect infants from diseases. Several studies have shown that early initiation of breastfeeding reduces the risk of neonatal mortality (UNICEF). It also helps in preventing uterine bleeding and hypothermia. Exclusive breastfeeding in the first six months has a positive impact on the child's life. During this period, an infant not exclusively breastfed has a higher risk of death. Hence, optimal breastfeeding (breastfeeding within $1 \mathrm{~h}+$ exclusive breastfeeding for the first six months) could reduce child mortality.

Good complementary feeding practice along with breastfeeding has played an important role in the nutritional status of children by reducing stunting significantly. Complementary feeding should be promoted with special focus on the education of the caregiver, fortifying complementary foods, creating awareness of the right age and required complementary food feeding frequency, etc.

According to NFHS 3 (2005-06) data, 23.4\% of children under age three were breastfed within one hour of birth. The share doubled by 2015-16. But the share of children in India aged 6-8 months receiving solid, semi-solid food and breast milk declined from $52.6 \%$ in $2005-06$ to $42.7 \%$ in $2015-16$.

We have constructed an index of child care practices using four important variables cited from the recent NFHS survey (2015-16) regarding child care: percentage of children under six months exclusively breastfed, percentage of children below three years breastfed within one hour of birth, percentage of children aged 6-8 months who were fed complementary foods and percentage of breastfed children in the age group 6-23 months who had a minimum dietary diversity. A normalised composite index has been constructed for all states. Each of these indicators of "childcare" is first normalised according to the formula:

$$
\text { Normalised Indicator }=\frac{\text { Actual Value }- \text { Minimum Value }}{\text { Maximum Value }- \text { Minimum Value }}
$$

The normalised child care index is then estimated as a simple average of the normalised values of the indicators.

The diagram shows the ranking of states based on the normalised childcare index - the higher the rank, the better-off the state is. The state ranking shows that Goa, Tamil Nadu, Kerala and Odisha fare well in child care practice while Punjab, Bihar, Rajasthan and UP are the worst-performing states (Fig. 3.16).

Proper child care practice is dependent on factors like knowledge and beliefs about child rearing, the health and nutritional status of care providers and the role in decision making and economic status of the care givers. Studies have shown that different programmes aimed at nutritional intervention and knowledge building has had a significant impact on child health status. 


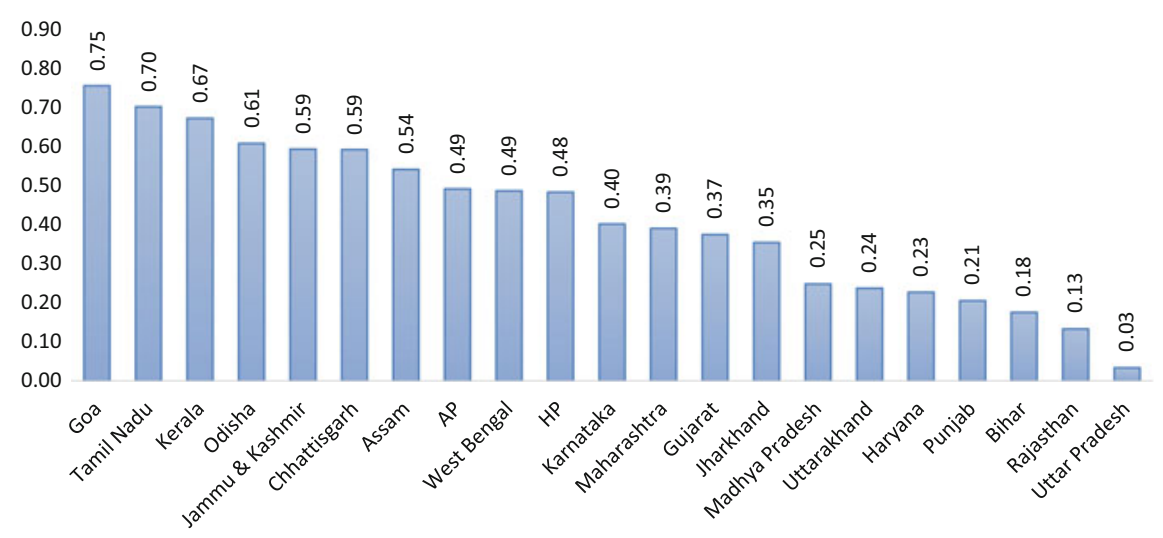

Fig. 3.16 Normalised child care index. Source NFHS-4

\subsubsection{Household Infrastructure and Amenities}

Rapid urbanisation comes with several challenges in terms of proper housing facilities, safe drinking water and sanitation. Access to basic amenities such as safe drinking water, toilet facilities and clean cooking fuel is fundamental to the health of its members. Access to regular piped drinking water on the premise implies women do not have to travel long distances for water every day. Use of unclean fuel exposes women to harmful smoke, which increases the chance of having respiratory diseases. Similarly, access to electricity also reduces day-to-day hardship. Clean fuel and electricity have a direct impact on women's health, and hence, influence child health too. Without proper access to safe drinking water and toilet facilities, the problem of malnutrition cannot be overcome.

There has been an improvement in access to housing amenities over the years. In 2005-06 nearly $88 \%$ of the population had access to an improved source of drinking water ${ }^{10}$; the share increased to $90 \%$ in $2015-16$. However, only $29.2 \%$ households (18.4\% in rural and $52.1 \%$ in urban India) have access to piped water into dwelling/yard/plot. In 2005-06, 29\% of households had improved toilet facility; the share increased to $48 \%$ in 2015-16. The improvement is impressive, but half the population still did not have access to basic household amenities in 2015-16, which has a serious impact on nutritional status. Lack of improved sanitation facilities increases the probability of getting diarrhoea, which reduces the positive impact of consuming healthy food.

We have created a composite index of household amenities by considering four variables: access to safe drinking water, improved toilet facilities (not shared), electricity as a source of lighting and clean fuel for cooking (LPG use). A normalised

\footnotetext{
${ }^{10}$ Include piped water, public taps, standpipes, tube wells, boreholes, protected dug wells and springs, rainwater and community reverse osmosis (RO) plants.
} 


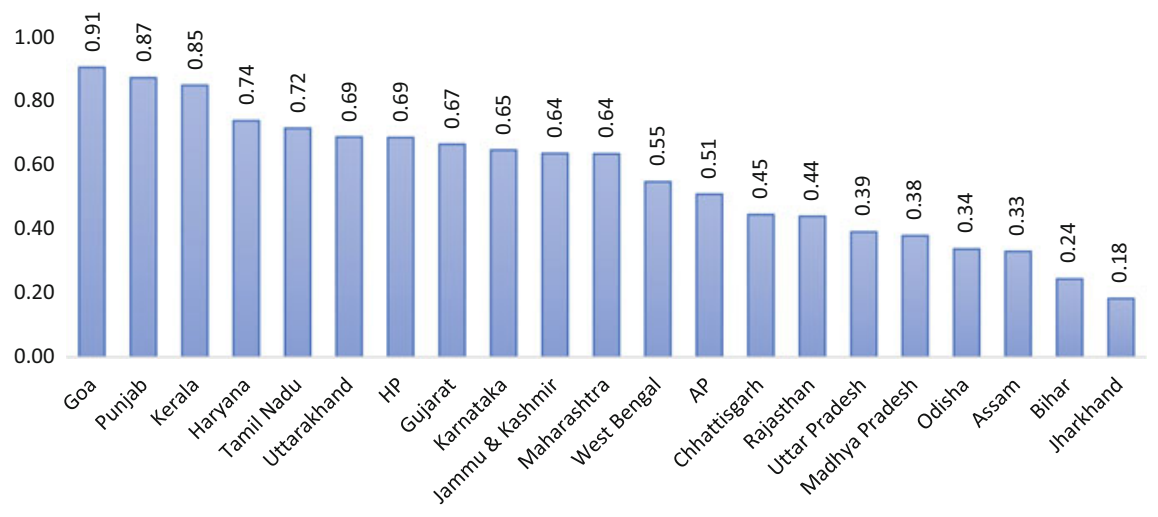

Fig. 3.17 Normalised index for housing amenities. Source NFHS-4

composite index has been constructed for all states. Each of these indicators of "housing amenities" is first normalised according to the formula:

$$
\text { Normalised Indicator }=\frac{\text { Actual Value }- \text { Minimum Value }}{\text { Maximum Value }- \text { Minimum Value }}
$$

The normalised index for housing amenities has then been estimated as a simple average of the normalised values of the indicators.

The ranking of normalised index for housing amenities shows that Goa, Punjab and Kerala did well while Assam, Bihar and Jharkhand lagged behind (Fig. 3.17).

\subsubsection{Access to Healthcare Facilities}

Nutrition plays a vital role in ensuring a healthy life for both men and women. However, women's nutrition assumes greater significance due to their complex association with children's nutritional status. There are several linkages between the nutritional status of women and children. Maternal malnutrition (iron deficiency) increases the risk of maternal mortality during childbirth. Malnutrition is both a cause and consequence of disease in adults and children. Maternal care includes supplementation with iron, folic acid or multiple micronutrients during pregnancy. Intake of iodine and iron during pregnancy helps in the development of an infant's nervous system. So, access to healthcare facilities becomes a significant factor affecting malnutrition. Access to healthcare facilities for pregnant and lactating women ensures the birth of children safely and vaccines keep children alive and healthy by protecting them against diseases.

In 2005-06, 12\% of pregnant women received full ante-natal care (ANC), 47\% of the children were delivered by health personnel and $35 \%$ received post-natal (PN) 


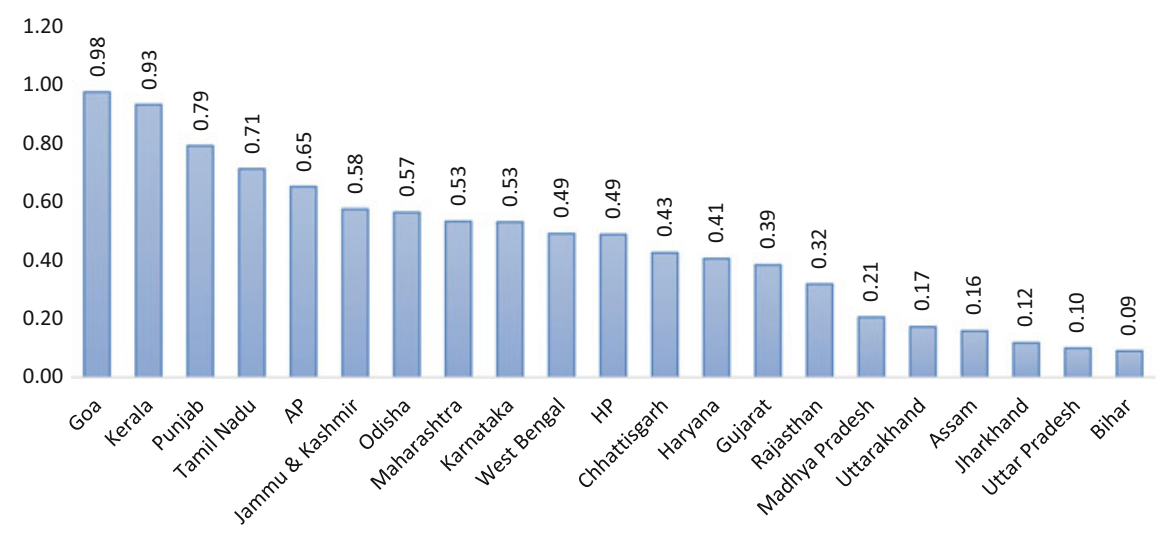

Fig. 3.18 Normalised index for access to healthcare. Source NFHS-4

check-ups within two days of birth. In 2015-16, these figures increased to $21 \%, 81 \%$ and $62.4 \%$ respectively. The percentage of children (12-23 months) receiving full immunisation increased from 43.5 to $62 \% .^{11}$

To construct the index for access to healthcare, we have considered four variables from the recent NFHS-4 data for 2015-16: the percentage of mothers who received full ANC, the percentage of mothers who received full PNC within 48 hours of delivery, percentage of delivery by health personnel and the percentage of children who received all vaccination. A normalised composite index has been constructed for all states. Each of these indicators of "access to healthcare" was first normalised according to the formula:

$$
\text { Normalised Indicator }=\frac{\text { Actual Value }- \text { Minimum Value }}{\text { Maximum Value }- \text { Minimum Value }}
$$

The normalised index for access to health care has then been estimated as a simple average of the normalised values of the indicators.

There have not been many changes in the ranking of access to healthcare performance in the last decade. Goa, Kerala, Punjab and Tamil Nadu rank up in the chart and Jharkhand, Uttar Pradesh and Bihar fare poorly (Fig. 3.18).

Finally, we have constructed a composite socio-economic index considering (averaging the values of) all four dimensions: education, child care, housing amenities and access to health care.

According to the ranking based on the normalised socio-economic index, Kerala, Goa and Tamil Nadu score high while Rajasthan, Jharkhand, Uttar Pradesh and Bihar perform badly in terms of basic socio-economic indicators (Fig. 3.19). The rank correlation between socio-economic index and malnutrition index is 0.77 , indicating a strong correlation between them.

\footnotetext{
${ }^{11} \mathrm{BCG}$, measles, and three doses of DPT and polio vaccine.
} 


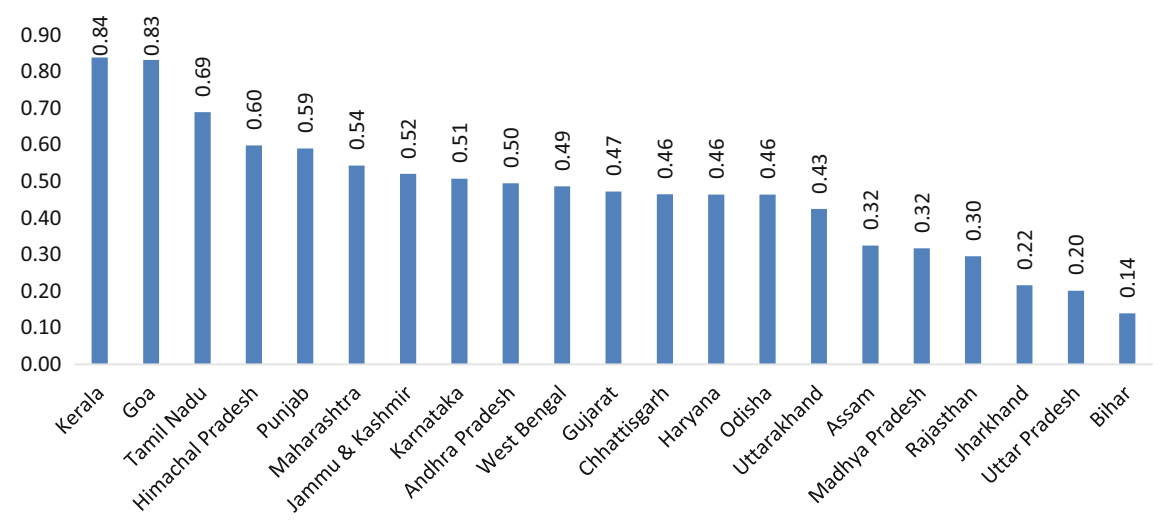

Fig. 3.19 Normalised socio-economic index. Source NFHS-4

\subsection{Concluding Remarks and Way Forward}

Although India's child nutrition rates have shown an improvement since 2005-06, we are still below the rates of progress experienced by other countries. At the current pace, India will achieve what China has achieved today by 2055 (Global Nutrition Report, 2015). Hence, more serious commitment is needed from the government to eradicate malnutrition completely by 2030 .

\section{Role of Agriculture in Reducing Malnutrition}

Some important results emerge from this study. The performance of the agricultural sector plays an important role in reducing malnutrition in India. A large section of the workforce depends on agriculture and allied activities as a source of livelihood. Food shortages and rising or volatile food prices also affect nutritional status. Hence, an improvement in productivity can solve the problem of food shortage and price stability, making food affordable to the vulnerable sections of the population. Apart from an increase in yield, diversification towards high-value agriculture (fruits, vegetables, fisheries and livestock) will ensure a diversified food basket, which will also ensure better nutrition. This is reflected in the changing consumption pattern of the Indian population, which shows a shift away from basic staple foods (NSSO; 2011-12). States like Kerala, Himachal Pradesh, Jammu and Kashmir and Goa that specialise in high-value agriculture also rank higher in the nutrition ladder. Punjab and Haryana have historically been consistent in terms of a high level of agricultural prosperity, Punjab performs well but Haryana lags behind in terms of nutritional outcome. States like Bihar, Odisha, UP and Rajasthan with low agricultural performance also show high rates of under-nutrition. However, it should be mentioned that since agricultural prosperity affects malnutrition by improving food security and reducing poverty, its impact on malnutrition and poverty will be manifested over the long-term. In recent years, Gujarat and Madhya Pradesh have experienced very high growth rates in agriculture, while Odisha experienced the highest growth in farm 
income. But this is not yet reflected in the indicators of malnutrition. These states still rank very low in the ranking based on malnutrition. As our research shows above, malnutrition is affected by several factors including access to hygiene and health services, female literacy, etc.; agricultural performance and prosperity is only one parameter, albeit an important one, in this complex equation of solving the problem of malnutrition.

\section{Multidimensional Approach to Reduce Malnutrition}

Agricultural performance, therefore, may be a necessary condition, but it is certainly not enough to ensure improved nutrition. The multidimensional nature of malnutrition requires intervention in a holistic manner. The two most important direct nutrition intervention programmes implemented in India are the Integrated Child Development Scheme (ICDS) and the Mid-day Meal Scheme (MDMS). These programmes were launched to address the nutritional needs of children and women. The ICDS scheme is the GOI's flagship programme launched in 1975 by the Ministry of Woman and Child Development and is one of the world's largest programme for early childcare and development. The beneficiaries under the scheme are children in the age group of 0-6 years and pregnant and lactating mothers. The objectives of the two schemes are (1) to improve the nutritional and health status of children in the targeted age group, (2) to lay the foundation for the proper psychological growth of children, (3) to minimise the incidence of mortality, morbidity, malnutrition and school dropouts and (4) to enhance the capacity of mothers to be able to take proper care of children. To achieve these objectives, the scheme offers a combination of six services - supplementary nutrition, pre-school non-formal education, nutrition and health education, immunisation, health check-ups and referral services (the last three health-related services are provided by Ministry of Health and Family Welfare) (icds-wcd.nic. in/icds). According to the CAG Report (22nd Report, 2012-13), the programme is plagued by organisational failures. Poor hygiene and lack of sanitation facilities, lack of medical kits and lack of well-trained staff are among the problems that plague Anganwadi centres where children are fed.

The mid-day meal scheme as a tool to promote education and supplement nutrition was adopted in some parts of India (Madras Municipal Corporation) before independence and, over the years, the number of states adopting this programme has increased. It became a centrally sponsored scheme under the name of National Programme of Nutritional Support to Primary Education (NP-NSPE) on August 15, 1995, when it was introduced in 2408 blocks; by 1997-98, the NP-NSPE was introduced in all blocks of the country. Food norms have been revised in recent years (2009) to ensure a balanced and nutritious diet to children of the upper primary group by increasing the quantity of pulses from 25 to $30 \mathrm{gms}$, vegetables from 65 to $75 \mathrm{gms}$ and decreasing the quantity of oil from 10 to $7.5 \mathrm{gms}$. This food assistance programme also suffers from organisational failures. Extreme cases of death due to improper food preparation have happened in some pockets of the country (Bihar), luckily not so frequently. But cases of children falling ill from stale food are quite common, which shakes the faith of parents in the scheme, leading them to withdraw their children from school. A proper system of vigilance should be introduced, 
including participants from various stakeholders, to ensure the quality of food. This scheme is instrumental in reducing hunger and malnutrition among children; hence, the shortcomings need to be corrected.

Nutritional education and health interventions were also initiated through the Nutrition Board and ICDS. But there were gaps in the implementation of these interventions because the workers lacked training. In our study, we have found that each state has specific reason(s) for underperformance in nutritional outcomes. A successful malnutrition reduction strategy is required with a special focus on specific areas relevant to each state.

Some states have declared independent state nutrition missions. Maharashtra was the first to launch a mission in the form of an autonomous, technical and advisory body in 2005. Subsequently, five other states followed in the footsteps of MaharashtraMadhya Pradesh, Uttar Pradesh, Odisha, Gujarat and Karnataka. But other than Maharashtra and Karnataka, these states could not bring about much improvement in the rates of under-nutrition.

Our study has shown that literacy, child care, sanitation and access to health care facilities have an immediate impact on malnutrition. These findings have important implications for policy interventions. According to the Census data, female literacy improved from 54\% in 2001 to $65 \%$ in 2011; there is still a lot of scope for improvement. Direct nutritional intervention through special nutrition benefit schemes (ICDS, mid-day meal), can play a critical role in child nutrition. Female literacy also has a positive effect on child care and access to health and sanitation. Hence, improving the female education status will have a multiplier effect on malnutrition, as access to these facilities is not only governed by the income of the household but also by knowledge about nutrient-enriched complementary foods, timing and handling of food, proper hygiene and so on. Liberal scholarship programmes for the girl child should be initiated in states to incentivise female education following the example of Kanyasree in West Bengal.

Everyone has a right to basic sanitation facilities (safe drinking water, toilet) and ensuring that very basic right is every government's duty. Only $3 \%$ of rural households in Bihar (5\% in Odisha and 3\% in UP) and 15\% of urban households (33\% in Odisha and UP) have access to piped water at their residence. The Modi government's new scheme "Nal se Jal" to provide piped drinking water to every household by 2024 is a welcome step and is expected to improve the drinking water situation in these states. Only $48 \%$ of the households have improved quality of (not shared) toilets. There is lot of scope for improvement. The Swachh Bharat Abhiyan is a recent programme aimed at improving sanitation that can play a role in eradicating under-nutrition. The scheme was launched in 2014 and as of now, 28 states and nine UTs have been declared 100\% open defecation free. Since October 2, 2014, close to 10.29 crore toilets have been built under the scheme (https://swachhbharatmission. gov.in/sbmcms/index.htm accessed on 17.3.2020). This will certainly have a positive effect on the nutrition outcomes as and when the results of next round (5) of NFHS come.

Micronutrients are important to improve nutritional status and the cost-effective way to do so is through biofortification of crops with essential nutrients such as iron, 
zinc and vitamin A. United Nations agencies recommend that the adoption of biofortification will not only improve the diet of household effectively but also improve the nutritional status of children. The Indian Council of Agricultural Research (ICAR) should partner with Harvest Plus programme of Consultative Group of International Agricultural Research (CGIAR) to adopt cost-effective, sustainable and innovative approach for nutrient-rich staple food crops.

Diversifying diets away from cereals can help improve nutritional outcomes. But currently, cereals dominate the food basket of most Indian households, resulting in diets that are deficient in protein and micronutrients. Encouraging the consumption of protein and micro-nutrient-rich foods will lead to a marked improvement in nutritional status. This would imply the inclusion of soya, meat, eggs and milk in nutrition intervention programmes. Soybean is one the cheapest source of protein, but soya does not figure in a big way in the Indian diet. A study by Gulati and Verma (2016) has shown that the percentage of households eating non-vegetarian food has increased. Egg is also a cheap source of protein compared to pulses today. Consumption of these nutritious foods can be promoted via distribution in the mid-day meals and Integrated Child Development programmes.

But as emphasised throughout this chapter, based on our econometric analysis, that malnutrition is a multidimensional problem. It requires a synchronised approach to improve basic hygiene facilities (toilets and safe drinking water), health facilities (immunisation, etc.) and female literacy. The latest programmes of the government in this direction are commendable, and one hopes that in due course, they will pay rich dividends, and India can assure its citizens a more healthy and nutritious future.

\section{Annexure}

See Figs. 3.20, 3.21, 3.22, 3.23 and Tables 3.9, 3.10, 3.11 and 3.12. 


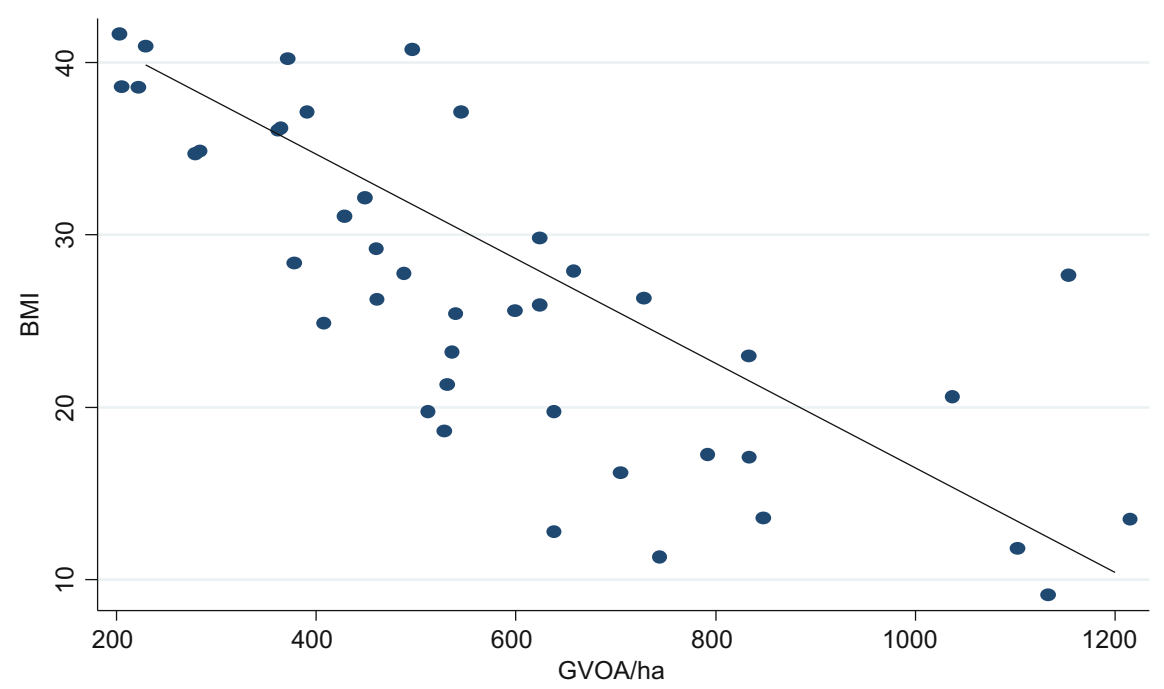

Fig. 3.20 Association between BMI and GVO from agriculture per ha of GCA

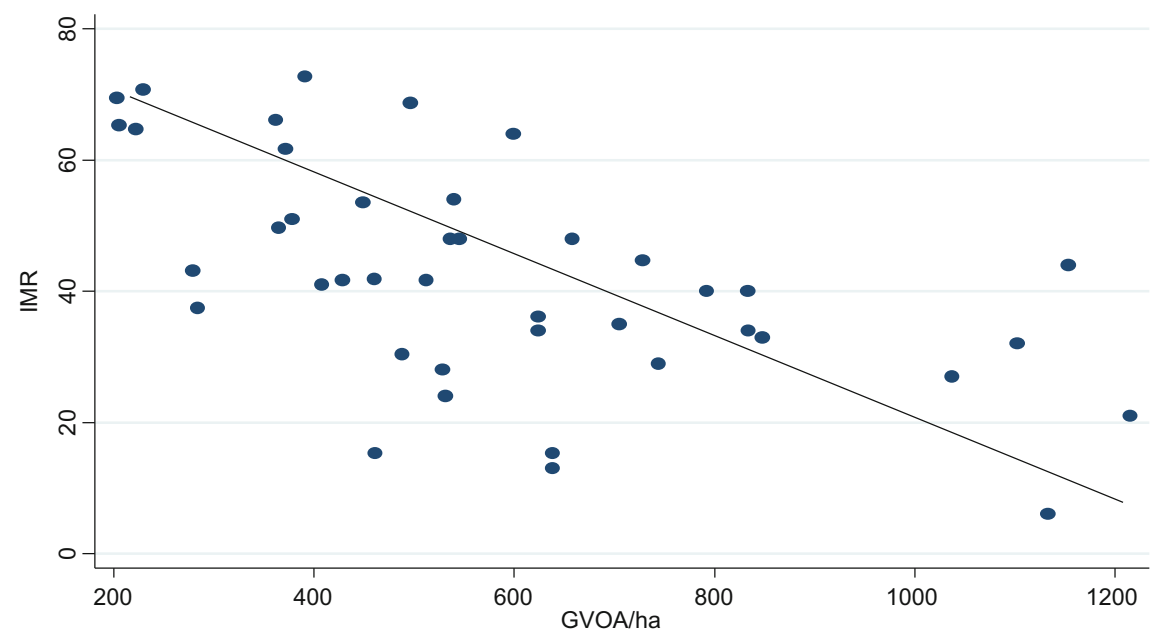

Fig. 3.21 Association between IMR and GVO from agriculture 


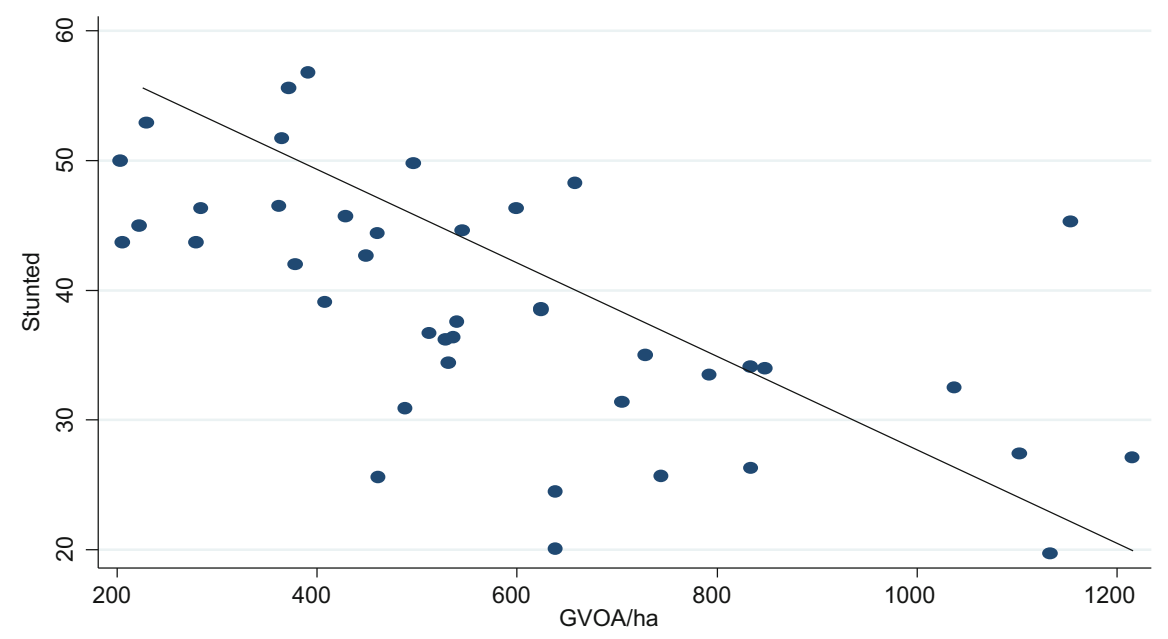

Fig. 3.22 Association between stunted children and GVO from agriculture per ha of GCA

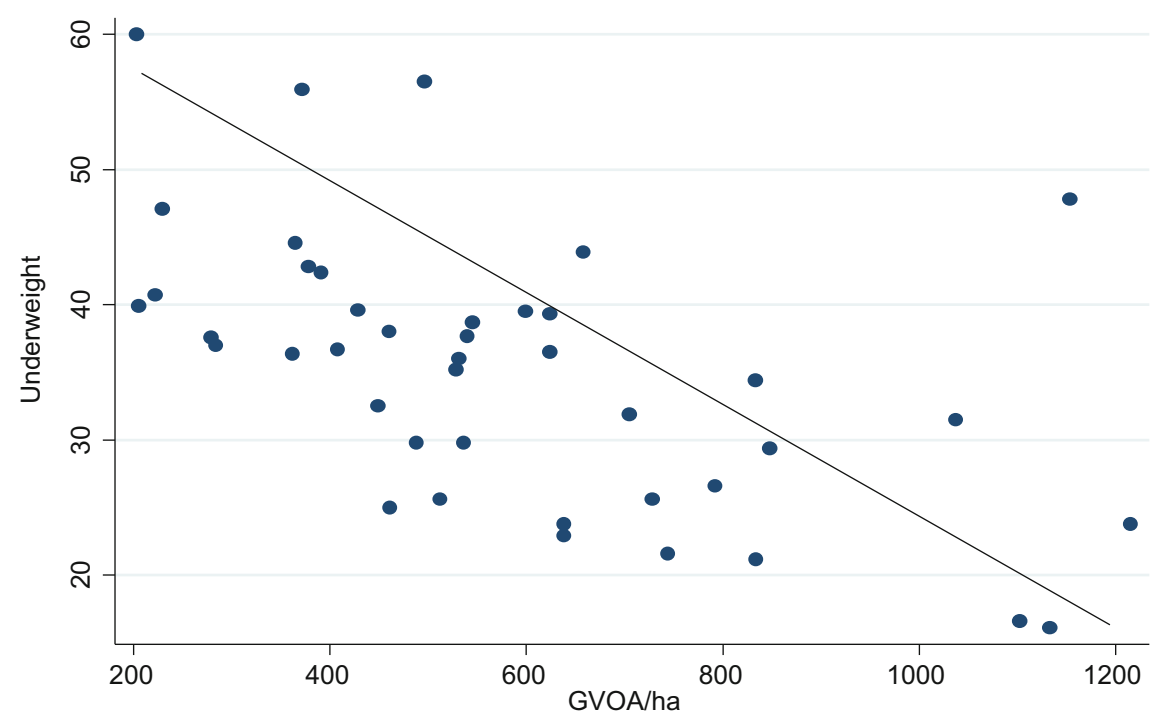

Fig. 3.23 Association between underweight children and GVO from agriculture per ha of GCA 
Table 3.9a Variable construction and data source

\begin{tabular}{l|l|l}
\hline $\begin{array}{l}\text { Variables and Data } \\
\text { Source }\end{array}$ & Definitions & Source \\
\hline $\begin{array}{l}\text { Total poverty (Pov) } \\
\text { Pead count ratio following } \\
\text { tendulkar methodology (2004-05 } \\
\text { and 2011-12) }\end{array}$ & Planning commission \\
\hline $\begin{array}{l}\text { Per capita GSDP from } \\
\text { agricultural and allied services } \\
\text { (TE 2004-05 and TE2011-12) }\end{array}$ & CSO and CENSUS \\
\hline NFEm-farm employment & $\begin{array}{l}\text { Percentage of workforce } \\
\text { employed in non-farm activities } \\
\text { (2004-05 and 2011-12) }\end{array}$ & NSSO \\
\hline $\begin{array}{l}\text { Surfaced road density } \\
\text { (SRD) }\end{array}$ & $\begin{array}{l}\text { Surfaced road } \\
\text { length/geographical area } * 1000 \\
\text { (2004-05 and 2011-12) }\end{array}$ & $\begin{array}{l}\text { Ministry of transport, road and } \\
\text { highays }\end{array}$ \\
\hline $\begin{array}{l}\text { Total literacy (Lit) } \\
\text { Total literacy rate of states (2001 } \\
\text { and 2011) }\end{array}$ & Census \\
\hline
\end{tabular}

Table 3.9b Variable construction and data source

\begin{tabular}{l|l|l|l}
\hline Variables & Construction & Data source & Year \\
\hline GVOA/ha & $\begin{array}{l}\text { Gross value of output per ha } \\
\text { of gross cropped area }\end{array}$ & CSO, MOSPI & $\begin{array}{l}\text { TE 2005-06 and TE } \\
2015-16\end{array}$ \\
\hline Literacy & Total literacy rate & NFHS & $2005-06$ and 2015-16 \\
\hline Stunted & $\begin{array}{l}\text { Percentage of stunted children } \\
\text { in the age group 0-59 months }\end{array}$ & NFHS & 2005-06 and 2015-16 \\
\hline Underweight & $\begin{array}{l}\text { Percentage of underweight } \\
\text { children in the age group } \\
\text { 0-59 months }\end{array}$ & NFHS and UNICEF & 2005-06 and 2015-16 \\
\hline IMR & $\begin{array}{l}\text { Infant mortality rate per 1000 } \\
\text { live births }\end{array}$ & NFHS and MOSPI & 2005-06 and 2015-16 \\
\hline Vac & $\begin{array}{l}\text { Percentage of children } \\
\text { receiving all basic } \\
\text { vaccinations }\end{array}$ & NFHS and UNICEF & 2005-06 and 2015-16 \\
\hline Delivery_HP & $\begin{array}{l}\text { Percentage of childbirth } \\
\text { assisted by health personnel }\end{array}$ & NFHS and UNICEF & 2005-06 and 2015-16 \\
\hline Bfed_1 h & $\begin{array}{l}\text { Percentage of children born in } \\
\text { the last five years, breastfed } \\
\text { within 1 h of birth }\end{array}$ & NFHS & 2005-06 and 2015-16 \\
\hline hh_toilet & $\begin{array}{l}\text { Percentage of households } \\
\text { having toilet facilities in their } \\
\text { house }\end{array}$ & NFHS & 2005-06 and 2015-16 \\
\hline
\end{tabular}


Table 3.10 Correlation matrix of poverty and factors impacting rural poverty

\begin{tabular}{l|l|l|l|l|l}
\hline & Poverty HCR & PCGSDPA & $\begin{array}{l}\text { Non-farm } \\
\text { employment }\end{array}$ & $\begin{array}{l}\text { Surfaced road } \\
\text { density }\end{array}$ & Literacy \\
\hline Poverty HCR & 1 & & & & \\
\hline PCGSDPA & $-0.60 * * *$ & 1 & & & \\
\hline $\begin{array}{l}\text { Non-farm } \\
\text { employment }\end{array}$ & $-0.68 * * *$ & $0.35 * *$ & 1 & & \\
\hline $\begin{array}{l}\text { Surfaced road } \\
\text { density }\end{array}$ & $-0.50^{* * * *}$ & $0.30^{* *}$ & $0.56^{* * * *}$ & 1 & 1 \\
\hline Literacy & $-0.58 * * *$ & $0.50^{* * *}$ & $0.57 * * *$ & $0.70 * * *$ & 1 \\
\hline
\end{tabular}

Table 3.11 Correlation matrix of adult malnutrition and factors impacting adult malnutrition

\begin{tabular}{l|l|l|l|l|l|l}
\hline & BMI & GVOA/ha & Flit & Mlit & HH_Toilet & Delivery_HP \\
\hline BMI & 1 & & & & & \\
\hline GVOA/ha & $-0.76^{* * *}$ & 1 & & & & \\
\hline Flit & $-0.72 * * *$ & $0.47 * *$ & 1 & & & \\
\hline Mlit & $-0.73 * * *$ & $0.55^{* * *}$ & $0.81 * * *$ & 1 & & \\
\hline HH_Toilet & $-0.65^{* * *}$ & $0.35^{* *}$ & $0.73 * * *$ & $0.46^{* *}$ & 1 & \\
\hline Delivery_HP & $-0.81^{* * *}$ & $0.54 * * *$ & $0.64 * * *$ & $0.69 * * *$ & $0.53 * * *$ & 1 \\
\hline
\end{tabular}




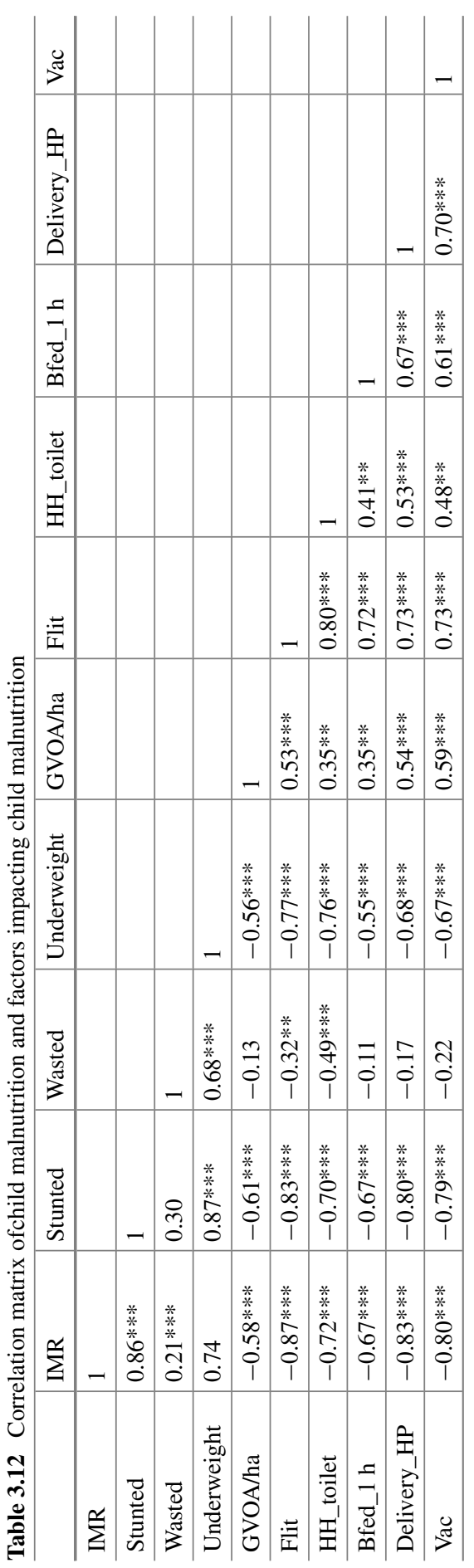




\section{References}

Bhagowalia, P., Kadiyala, S., \& Headey, D. (2012). Agriculture, income and nutrition linkages in India: Insights from a nationally representative survey. International Food Policy Research Institute.

Borooah, V. K. (2002). The role of maternal literacy in reducing the risk of child under nutrition in India. University of Ulster and ICER.

Cervantes-Godoy, D., \& Dewbre, J. (2010). Economic importance of agriculture for poverty reduction. OECD Food, Agriculture and Fisheries Working Paper No. 23. Paris: Organisation for Economic Co-operation and Development.

Commission, P. (2014). Report of the expert group to review the methodology for measurement of poverty. New Delhi: Government of India.

CSO. (Various Issues). State-wise Gross Domestic Product. New Delhi: Ministry of Statistics \& Programme Implementation, Government of India.

Directorate of Economics and Statistics (2015). Agricultural Statistics at a Glance. New Delhi: Ministry of Agriculture. Government of India.

Fan, et al. (2007). Investment, subsidies, and pro-poor growth in rural India. Discussion Paper No. 00716. New Delhi: IFPRI.

Gillespie, S. and S. Kadiyala (2011. Exploring the Agriculture-Nutrition Disconnect in India. 2020 IFPRI Conference Brief 20: Leveraging Agriculture for Nutrition and Health.

Gulati, A., Kumar, A. G., Shreedhar, G., \& Nandakumar, T. (2012). Agriculture and malnutrition in India.Food and Nutrition Bulletin, 33(1), 74-86.

Headey, D. (2014). An analysis of trends and determinants of child under nutrition in Ethiopia, 2000-2011 . Working Paper No-70. International Food Policy Research Institute (IFPRI).

Jose, S., \& Navaneetham, K. (2008). A factsheet on women's malnutrition in India. Economic and Political Weekly, 61-67.

MoSPI, (Various Issues). State wise estimates of Value of Output from Agriculture and Allied Activities. New Delhi: Ministry of Statistics and Programme Implementation, Government of India.

NFHS-4 (2005). National Family Health Survey 2005-06 . International Institute for Population Sciences (IIPS).

NFHS-4 (2017). National Family Health Survey 2015-16 . International Institute for Population Sciences (IIPS).

Planning Commission. (2014). Report of the expert group to review the methodology for measurement of poverty. Government of India, New Delhi.

Radhakrishna, R., \& Ravi, C. (2004). Malnutrition in India: Trends and determinants. Economic and Political Weekly, 671-676.

Ramji, S. (2009). Impact of infant \& young child feeding \& caring practices on nutritional status \& health. Indian Journal of Medical Research, 130(5), 624-626.

UNICEF. (1990). Strategy for Improved Nutrition of Children and Women in Developing Countries. A UNICEF Policy Review. New York: UNICEF.

United Nations Children's Fund. (2013). Improving child nutrition: The achievable imperative for global progress (pp. 1-14). New York: UNICEF.

Vepa, S. S., Umashankar, V., Bhavani, R. V., \& Parasar, R. (2014). Agriculture and child undernutrition in India: A state level analysis. Working Paper 86/2014. Chennai: Madras School of Economics.

World Bank. (2007). From agriculture to nutrition: Pathways, synergies and outcomes. No. 40196GLB. Washington, DC: Agriculture and Rural Development Department. The World Bank. 
Open Access This chapter is licensed under the terms of the Creative Commons Attribution 4.0 International License (http://creativecommons.org/licenses/by/4.0/), which permits use, sharing, adaptation, distribution and reproduction in any medium or format, as long as you give appropriate credit to the original author(s) and the source, provide a link to the Creative Commons licence and indicate if changes were made.

The images or other third party material in this chapter are included in the chapter's Creative Commons licence, unless indicated otherwise in a credit line to the material. If material is not included in the chapter's Creative Commons licence and your intended use is not permitted by statutory regulation or exceeds the permitted use, you will need to obtain permission directly from the copyright holder.

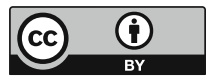

